\title{
WestVirginiaUniversity
}

THE RESEARCH REPOSITORY @ WVU

Graduate Theses, Dissertations, and Problem Reports

2013

\section{Monumento Piece for symphonic orchestra, 8'30"}

\author{
Rafael Langoni Smith
}

Follow this and additional works at: https://researchrepository.wvu.edu/etd

\section{Recommended Citation}

Smith, Rafael Langoni, "Monumento Piece for symphonic orchestra, 8'30"' (2013). Graduate Theses, Dissertations, and Problem Reports. 6660.

https://researchrepository.wvu.edu/etd/6660

This Thesis is protected by copyright and/or related rights. It has been brought to you by the The Research Repository @ WVU with permission from the rights-holder(s). You are free to use this Thesis in any way that is permitted by the copyright and related rights legislation that applies to your use. For other uses you must obtain permission from the rights-holder(s) directly, unless additional rights are indicated by a Creative Commons license in the record and/ or on the work itself. This Thesis has been accepted for inclusion in WVU Graduate Theses, Dissertations, and Problem Reports collection by an authorized administrator of The Research Repository @ WVU. For more information, please contact researchrepository@mail.wvu.edu. 


\title{
Optimization of Pulsed-Vacuum Osmotic Dehydration of Blueberries
}

\author{
Alexandra Marie Smith \\ Thesis submitted \\ to the Davis College of Agriculture, Natural Resource \&Design \\ at West Virginia University \\ in partial fulfillment of the requirements for the degree of \\ Master of Science in \\ Nutritional and Food Science \\ Litha Sivanandan, Ph.D., Chair \\ P. Brett Kenney, Ph.D., Co-Chair \\ Jacek Jaczynski, Ph.D. \\ Department of Animal and Nutritional Sciences
}

Morgantown, West Virginia

2015

Keywords: Osmotic dehydration, Pulsed vacuum osmotic dehydration, vacuum impregnation, Blueberries, Hydrodynamic mechanism C)2015Alexandra Marie Smith 


\title{
ABSTRACT \\ Optimization of Pulsed-Vacuum \\ Osmotic Dehydration of Blueberries
}

\author{
Alexandra Marie Smith
}

Fruit drying is energy intensive (thermal efficiency 25-50\%). However, improved efficiency is possible if phase change during the process is minimized. To minimize phase change and simultaneously increase product yield and quality, osmotic dehydration and pulsedvacuum osmotic dehydration can be applied to maximize water removal before final drying. The objective of this study was to characterize the effect of vacuum, osmotic solution temperature and concentration, and treatment duration on blueberry mass transfer. Frozen blueberries were exposed to 2 temperatures $\left(25\right.$ or $\left.50^{\circ} \mathrm{C}\right), 2$ sugar solution concentrations ( 45 or $65^{\circ}$ Brix), 2 vacuum treatments (no vacuum or 50 mbar), and 3 duration treatments $(180,240$, or 300 minutes). This design generated 24 treatment combinations that were nested in ${ }^{\circ}$ Brix as a balanced incomplete block design. Following treatments, blueberries were conventionally dehydrated at $57.2^{\circ} \mathrm{C}$ for 6.5 hours. Higher concentration of osmotic solution increased blueberry sugar gains by $62 \%$ compared to sugar gains at the lower concentration. Time affected sugar gain at both concentrations $(\mathrm{p}<0.0001)$. Blueberry ${ }^{\circ}$ Brix increased by $13.03,17.29$, and $17.68^{\circ}$ Brix at 180, 240, and 300 minutes, respectively. Solution concentration, temperature, and time affected percent yield after conventional drying $(\mathrm{p}<0.0001, \mathrm{p}=0.0004, \mathrm{p}<0.0001$, respectively). Higher temperatures increased yield of the final product compared to the lower temperature. Water activity appeared to be affected by an interaction between solution concentration and temperature $(\mathrm{p}=0.0210)$. These low temperature processes can be used commercially to reduce water activity of high moisture products and decrease the processing time; thereby, improving yield and producing minimally processed fruit products with marginal changes in color, texture, aroma, and flavor. 


\section{Acknowledgements}

I would like to thank all members of my committee, Litha Sivanandan, P. Brett Kenney, and Jacek Jaczynski, for their invaluable guidance and support. I would also like to thank the National Science Foundation's ADVANCE IT Program and the Branch Banking and Trust Company's CRA / Community Development Donation Fund for helping fund this research. Special thanks to Ida Holaskova for assisting me with the statistical analysis. I would also like to thank Sarah Beamer and Tammy Webster for help using and procuring equipment. Johni-Ann Sims and Alicia Pownall were integral to my research with helping weigh samples and making solutions. I greatly appreciated all the work that Susan Slider has helped me with. Without her guidance and explanations in the lab, I would have been very confused with most of the equipment.

I also greatly appreciate all the help from my family, financially and pushing me through graduate school. I also would like to thank my friends for their constant support. 


\section{Table of Contents}

Abstract $\quad$ ii

Acknowledgements $\quad$ iii

Table of Contents $\quad$ iv

List of Figures $\quad$ V

Chapter 1: Literature Review

Introduction 1

Mechanism of Osmotic Dehydration 2

Modeling 5

Factors Affecting Osmotic Dehydration $\quad 7$

$\begin{array}{lr}\text { Chemical and Physical Changes } & 12\end{array}$

$\begin{array}{ll}\text { Microbiological Concerns } & 15\end{array}$

Industrial Application $\quad 16$

$\begin{array}{lr}\text { Summary } & 18\end{array}$

$\begin{array}{ll}\text { References } & 20\end{array}$

Chapter 2: Effect of Processing Parameters on Dried Blueberry Yield and Water Activity

$\begin{array}{ll}\text { Introduction } & 24\end{array}$

Materials and Methods and Statistical Design 26

$\begin{array}{ll}\text { Results and Discussion } & 28\end{array}$

Conclusion $\quad 32$

$\begin{array}{ll}\text { References } & 39\end{array}$

Chapter 3: Effect of Vacuum Pressure on Dried Blueberry Yield and Water Activity $\begin{array}{ll}\text { Introduction } & 41\end{array}$

Materials and Methods and Statistical Design 41

Results and Discussion $\quad 42$

Conclusion 43

$\begin{array}{ll}\text { References } & 46\end{array}$ 


\section{List of Figures}

Figure 1: Effect of temperature on water loss/solid gain $\quad 19$

Figure 2: Effect of ratio of sample to solution on the water loss and solid gain 19

Figure 3: Schematic of the pulsed vacuum osmotic dehydration apparatus 33

Figure 4: Effect of solution concentration and temperature on blueberry weight change 34

Figure 5: Effect of solution concentration on blueberry sugar gains 34

Figure 6: Effect of time on blueberry sugar gains 35

Figure 7: Effect of solution concentration and temperature on percent yield after OD 35

Figure 8: Effect of solution concentration on percent yield after CD 36

Figure 9: Effect of temperature on percent yield after CD 36

Figure 10: Effect of time on percent yield after CD 37

Figure 11: Effect of vacuum pressure on percent yield after CD 37

Figure 12: Effect of solution concentration and temperature on final water activity $\quad 38$

Figure 13: Effect of vacuum pressure on final water activity 38

Figure 14: Effect of vacuum pressure on percent yield after OD 44

Figure 15: Effect of vacuum pressure on percent yield after OD 44

Figure 16: Effect of vacuum pressure on final water activity 45 


\section{Chapter 1: Literature Review}

\section{Introduction}

Osmotic dehydration (OD) is a process that helps remove water from foods (especially fruits) before conventional oven dehydration. OD begins by placing fruit into a hypertonic solution, which causes a higher osmotic pressure outside of the fruit (Singh et al. 2010). Removal of water from the fruit is countered with simultaneous diffusion of the solutes from the solution. Due to the selectively permeable properties of the fruit surface, water loss from the fruit is maximized while larger molecules remain inside the fruit. As described by Shi and Le Maguer (2003), when a sample is placed in an osmotic solution, the first layer of cells at the surface of the fruit exhibits water loss. A concentration gradient then occurs between the first and second layer of cells. This second layer begins to lose water to the first layer, where the first layer again loses water to the osmotic solution. Eventually, the middle layer begins to lose water to the previous layer until diffusion of all layers reaches equilibrium. Unfortunately, semi-permeable membranes are not perfectly selective. Nutrients present in the food can also be diffused with the water into the solution, which modifies the nutritional and organoleptic features of the fruit (İspir and Türk Toğrul, 2009). These nutrients can be vitamins, such as vitamins A and C, minerals, such as potassium, and natural antioxidants, such as phenols and anthocyanins.

Another process of interest is vacuum impregnation (VI). VI is achieved by decreasing the external pressure on the fruit while submersed in the solution (Derossi et al., 2012). Since there is a higher pressure inside the fruit, liquids and gases that are inside begin to migrate out of the fruit, creating space inside the cells. External pressure is subsequently elevated back to atmospheric pressure, causing the external solution to impregnate the fruit. Other goals of using VI are to enhancement of the nutritional and functional components of fruit, and to help 
reduction of microbial growth and some decomposition processes. Anti-browning, antimicrobial, and anti-freezing agents can be used to attain these benefits (Derossi et al. 2012). For example, Cruz et al. (2009) used VI with antifreeze protein to improve frozen storage conditions and reduce subsequent thaw losses of watercress leaves.

When OD and VI are alternated, the process is called pulsed vacuum osmotic dehydration (PVOD). PVOD involves immersing fruit in a hypertonic solution and decreasing the external pressure for a short time, followed by a relatively longer OD interval at atmospheric pressures (Escriche et al., 2000). An example cycle would consist of 15 min under a vacuum followed by OD for $3 \mathrm{~h}$. Hypertonic solution enters the pores of the fruit through the hydrodynamic mechanism (HDM) (Chiralt and Talens, 2004), which will be discussed later. During the vacuum phase, mass transfer rates and solid-liquid interface areas are increased; these increases cause a rapid evacuation of water with a decrease in the water activity of fruit. Though there is less moisture in the fruit, color and texture attributes are very comparable to fresh fruit due to less damage to cellular structures (Escriche et al., 2000). This review focuses on the mechanisms involved in mass transfer, factors affecting mass transfer, physical and chemical changes in fruits, and industrial application.

\section{Mechanism}

Rate of mass transfer can be described by the broad equation:

$$
\text { Flux } \sim \frac{\text { Driving force }}{\text { Resistance }}
$$

In order to appreciate how mass transfer occurs during osmotic dehydration, understanding exactly how driving force is maintained and how resistance is reduced are key first steps. 
To help explain mass transfer, one should consider Fick's laws of diffusion. Fick's first law of diffusion describes how the diffusive flux is affected by the concentration under the assumption of steady state (Taylor and Krishna, 1993). Movement of particles goes from areas of high concentration to areas of low concentration. This movement occurs at a rate that is relative to the concentration gradient. The formula for Fick's law in one dimension is described by Shi and Le Maguer 2002:

$$
J=D\left(\frac{\delta C_{i}}{\delta z}\right)
$$

where $\mathbf{J}$ is the diffusion flux [(amount of substance) per unit area per unit time], $\mathrm{D}$ is the diffusion coefficient $\left[\mathrm{m}^{2}\right.$ time $\left.{ }^{-1}\right], \mathrm{C}_{\mathrm{i}}$ is the concentration of the component [amount of substance per unit volume], and $\mathrm{z}$ is the direction [length or depth]. The driving force for this diffusion is the quantity $-\left(\frac{\delta C_{i}}{\delta z}\right)$ which is the concentration gradient for ideal mixtures (Welti-Chanes et al., 2002).

When an unsteady state of diffusion occurs, Fick's second law is at play. As described by Welti-Chanes et al. 2002, this law determines how diffusion affects concentration over time:

$$
\frac{\delta C_{A}}{\delta t}=D_{A B}\left(\frac{d^{2} C_{A}}{d z^{2}}\right)
$$

where $\mathrm{D}_{\mathrm{AB}}$ is the diffusion coefficient in a binary system [length ${ }^{2}$ time $\left.^{-1}\right], \mathrm{C}_{\mathrm{A}}$ is concentration of the component [amount of substance per unit volume], $\mathrm{z}$ is the direction [length], and $\mathrm{t}$ is time [s]. Since OD occurs over long periods of time, this formula is quite important in accounting for decreases of osmotic concentration, which in turn reduces the driving force of diffusion (WeltiChanes et al., 2002).

Another important aspect of OD is Reynolds number (Re). This number is used when agitation of the solution occurs. Re helps determine the character of the motion of a flowing liquid and is defined as the ratio of inertial forces to viscous forces in flow. For a cylindrical 
vessel stirred by a central rotating agitator, Re can be defined according to Toledo 2007, by the equation:

$$
R e=\frac{D v p}{\mu}
$$

where $\mathrm{v}$ is the rotational speed, $\mathrm{D}$ is the diameter of the agitator, $\mathrm{p}$ is the density of the solution $\left(\mathrm{kg} / \mathrm{m}^{3}\right)$, and $\mu$ is the absolute viscosity of the fluid ( $\left.\mathrm{Pa}^{*} \mathrm{~s}\right)$. When the value of Re is below 2100, the flow is considered laminar; when Re is above 2100, the flow is considered turbulent in low viscosity fluids (Toledo, 2007).

When a vacuum is drawn during OD, a solid-fluid system arises. It is essential to contemplate fruit's naturally porous structure when considering mass transfer. This fast mass transfer mechanism is called HDM and occurs when a porous solid is submerged in a liquid. The gas inside the solid's pores is compressed, while the external liquid enters the pores with the gas compression. The compression ratio of fruit gas is shown by Martin-Esparza and GonzalezMartinez 2008 in the equation:

$$
r=\frac{p_{2}+p_{c}}{p_{1} r}
$$

where $\mathrm{p}_{2}$ is the atmospheric pressure, $\mathrm{p}_{\mathrm{c}}$ is the capillary pressure, and $\mathrm{p}_{1}$ is the vacuum pressure. As demonstrated by Shi et al., fruit porosity coefficients can be found by the equation:

$$
\varepsilon_{0}=\frac{X}{1-\frac{P t}{P_{\text {atm }}}}
$$

where $\varepsilon_{\mathrm{o}}$ is the effective porosity of the sample, $\mathrm{X}$ is a specific constant for each fruit, $\mathrm{P}_{\mathrm{t}}$ is vacuum pressure in each treatment at time (mbar), and $\mathrm{P}_{\mathrm{atm}}$ is normal atmospheric pressure (1030 mbar). When there is no pressure change, impregnation will occur mainly from capillary pressure (Fito et al., 2002). 
Capillary pressure is the difference in pressure across the interface between two immiscible components, in this case, fruit and a hypertonic solution. Capillary pressure can be described by Du and Zhao 2011 in the equation:

$$
p_{c}=\sigma K
$$

where $\sigma$ is the surface tension coefficient and $\mathrm{K}$ is the interfacial curvature. Pore penetration by a solution can be calculated by Fito 1994 in the equation:

$$
-\Delta \mathrm{p}+\left(\frac{32 \mu z^{2}}{D^{2}}\left(x_{v} \frac{d x_{v}}{d t}\right)\right)=0
$$

where $\mu$ is solution viscosity and $x_{v}$ is a volume fraction of the pore occupied by the solution.

\section{Modeling}

Beneficial models of water loss, solid gain, and structural changes can be made by using the aforementioned concepts. Barat et al. (2001) studied the sample volume change of apple slices using concentrations of $25-65^{\circ} \mathrm{Brix}$ at 30,40 , and $50{ }^{\circ} \mathrm{C}$ and at atmospheric pressure or vacuum pressure. Sample volume variation was estimated as relative change referred to the initial value $\left(\Delta \mathrm{V}^{\circ}\right)$, while the change in volume of the sample at liquid phase was estimated by Barat et al. 2001 in the equation:

$$
\Delta \mathrm{V}^{L P}=\frac{p^{\circ}}{M_{0}^{\circ}}\left[\left(M_{t}^{\circ} \frac{x_{t}^{w}+x_{t}^{s S}}{p_{t}^{L P}}\right)-\left(M_{0}^{\circ} \frac{x_{0}^{w}+x_{0}^{S S}}{p_{0}^{L P}}\right)\right]
$$

where $\Delta \mathrm{V}^{\mathrm{LP}}$ is the change in volume of the sample at liquid phase, $\mathrm{M}_{0}{ }^{\circ}$ is the initial sample weight, $\mathrm{p}_{0}{ }^{\circ}$ is the initial density, $\mathrm{M}_{\mathrm{t}}{ }^{\circ}$ is the sample weight at time, $\mathrm{x}_{\mathrm{t}}{ }^{\mathrm{w}}$ is the mass fraction of water in the sample at time, $\mathrm{x}_{\mathrm{t}}^{\mathrm{ss}}$ is the mass fraction of soluble solids in the sample at time, $\rho_{\mathrm{t}}^{\mathrm{LP}}$ is the density of the liquid phase at time, $\mathrm{x}_{0}{ }^{\mathrm{w}}$ is the initial mass fraction of water in the sample, and $\mathrm{x}_{0}{ }^{\mathrm{ss}}$ is the initial mass fraction of soluble solid in the sample. Liquid phase densities were estimated again by Barat et al. 2001 with the equation: 


$$
p^{L P}=\frac{1}{\left(\frac{1-z^{S S}}{1000}\right)+\left(\frac{z^{S S}}{1590}\right)}
$$

where $\mathrm{z}^{\mathrm{ss}}$ is the mass fraction of soluble solids in food liquid phase. The total volume change $\left(\Delta \mathrm{V}_{\mathrm{t}}{ }^{\circ}\right)$ can be found by Barat et al. 2001 in the equation:

$$
\Delta \mathrm{V}_{\mathrm{t}}{ }^{\circ}=\Delta \mathrm{V}^{\mathrm{LP}}+\Delta \mathrm{V}^{\mathrm{GP}}+\Delta \mathrm{V}^{\mathrm{SM}}
$$

where GP and SM are the gas phase and solid matrix. By plotting $\Delta \mathrm{V}_{\mathrm{t}}^{\circ}$ against $\Delta \mathrm{V}_{\mathrm{t}}^{\mathrm{LP}}$, a difference between PVOD and OD treatments and linear relationships for each of their conditions were found.

Contribution of gas phase and liquid phase to the total sample volume variation $\left(\Delta \mathrm{V}^{\mathrm{GP}} / \Delta \mathrm{V}^{\circ}\right.$ and $\left.\Delta \mathrm{V}^{\mathrm{LP}} / \Delta \mathrm{V}^{\circ}\right)$ is attained by the equations obtained by Barat et al. 2001:

$$
\begin{aligned}
& \Delta \mathrm{V}^{\circ}=\mathrm{s}_{1} \Delta \mathrm{V}^{\mathrm{LP}} \\
& \frac{\Delta V^{G P}}{\Delta V^{\circ}}=1-\frac{1}{s_{1}}
\end{aligned}
$$

where $\mathrm{s}_{1}$ is value of the slope from the fit line of plotting $\Delta \mathrm{V}_{\mathrm{t}}^{\circ}$ against $\Delta \mathrm{V}_{\mathrm{t}}{ }^{\mathrm{LP}}$. Barat et al. found that the gas phase's contribution to the total volume change was between .25 and .45 (25\% and $45 \%$ ), while the remaining contribution was due to the liquid phase. They also noted that the higher gas phase contribution occurred when osmotic solution concentration and viscosity were the highest. The contribution of liquid phase was observed to be the greatest when the external solution entered the sample pores. Pressure gradients produced inside the cell promotes cell water loss, which is more effective when lower concentration and viscosity solutions are used due to lesser pressure drops. Overall, they were able to explain changes in sample volume due to the fruit-liquid phase's volume decrease in line with transfer of soluble solids and water, and sample volume change during the gas phase that caused cell matrix shrinkage (Barat et al., 2001). 


\section{Factors}

\section{Temperature}

Mass transfer of solids and water depends on many factors. Temperature affects the kinetic activity of solutes. Increasing the temperature increases the diffusion rate because energy is added to the particles (Figure 1). Particles with added energy are able to move through food material more readily. Respectively, decreasing temperatures will decrease diffusion rates by reducing energy of the particles (Martínez-Valencia et al., 2011; Singh et al., 2010). Shi et al. (1995) tested strawberries, apricots, and pineapple in a solution of $65^{\circ} \mathrm{Brix}$, at temperatures between $30-50{ }^{\circ} \mathrm{C}$ from $15 \mathrm{~min}$ up to $240 \mathrm{~min}$. All of OD treatments were performed at 3 pressures: normal atmosphere, vacuum at $100 \mathrm{mbar}$, and pulsed vacuum at $100 \mathrm{mbar}$ for $5 \mathrm{~min}$. They were able to identify that temperature increase had a favorable effect on the rate of diffusion. Sugar gains occurred primarily in the first hour, and eventually reached equilibrium causing a reduction in the rate of diffusion. Changes in sugar gains between the different fruit species were attributed to differences between apricot, strawberry, and pineapple tissues. While higher temperatures do produce faster diffusion rates, they also noted that lower temperatures improved quality attributes due to decreased heat damage to the fruit along with preservation of natural colors and flavors.

\section{Concentration}

Since diffusion is achieved by solutes moving down to lower concentration gradients, rate of diffusion is directly affected by concentration of the osmotic solution. Higher concentration differences will result in higher diffusion rates. Eventually, mass transfer will slow down as equilibrium in concentration is reached (Stojanovic and Silva, 2007). İspir and Türk Toğrul (2009) tested apricots with sucrose, glucose, fructose, maltodextrin, and sorbitol osmotic 
solutions. The concentrations of solutions were $40,50,60$, and $70{ }^{\circ}$ Brix and the temperatures were 25,35 , and $45^{\circ} \mathrm{C}$, respectively with a fruit to solution ratio of $1: 25$. Samples were in solution for 8 days. They found that increasing solution concentration accelerated and increased water loss while improving solid gains. They stated that the swift loss of water from the fruit during the first hour of OD was caused by a large osmotic driving force between the hypertonic solution and the fruit. Giraldo et al. (2003) found similar results as İspir and Türk Toğrul (2009) when they osmotically dehydrated mango; however, they saw different outcomes in their 65 ${ }^{\circ}$ Brix experiment. They used osmotic solution concentrations of $35,45,55$, and $65{ }^{\circ}$ Brix at a temperature of $30{ }^{\circ} \mathrm{C}$ with a vacuum pressure of $50 \mathrm{mbar}$ for $10 \mathrm{~min}$ at the beginning of the experiments. They found that optimal concentration of solution for mango was $45^{\circ}$ Brix and the least optimal concentration was $65^{\circ}$ Brix. Effects of concentration and type of solution are dependent on the fruit and observed outcomes in mango could be interpreted by the reduction of HDM in the fruit's tissues due to a higher sugar concentration. This reduction could be explained by the osmotic solution entering capillaries, then being pushed out of the pores when the external cells exhibit water loss causing internal cells to breakdown.

\section{Vacuum Pressure}

Another important factor is the vacuum pressure at which the treatment is given.

Generally, as a vacuum pressure is increased; fruit pores will expand and cause a deformation in the fruit. This deformation allows for gases in the fruit to escape, giving room for solution when the fruit is returned to atmospheric pressure. Martínez-Valencia et al. (2011) tested cantaloupe with sucrose solution concentrations: 40,50 , and $60^{\circ}$ Brix, at temperatures of $30,45,60{ }^{\circ} \mathrm{C}$ and at vacuum pulses of 0,300 , and 600 mbar. They stated that when OD, applied at atmospheric pressure, is used at a vacuum pressure of 331.2 mbars, mass transfer in melons is maximized 
because of the increase in contact area area. Solution-fruit areas are affected due to vacuum pressures initiating a deformation in cell structures that helps increase the contact area, thus improving diffusion of the osmotic solution. However, Shi et al. (1995) found that OD under a vacuum pressure of 100 mbar was enough to produce a significant increase in water loss in both pineapple and apricots. Differences in vacuum pressures needed to create a significant change in water loss are due to the larger pore size of pineapple and apricots compared to cantaloupe.

\section{Fruit to Solution Ratio}

Material mass to solution ratio is also an important factor to consider. İspir and Türk Toğrul (2009) used fruit to solution ratios of 1:4, 1:8, 1:12, 1:16, and 1:20 using solutions of $70 \%(\mathrm{w} / \mathrm{w})$ maltodextrin and 70\% (w/w) glucose. They found that decreasing sample to solution ratio; both water loss and solid gain could be increased. When the osmotic solution becomes diluted, concentration gradient loses its driving force and causes a decrease in mass transfer rate. Dilution of the osmotic solution can be avoided by reducing the ratio of fruit to hypertonic solution (Figure 2).

\section{Length of Treatment}

Another factor is the length of osmotic treatment. Rizzolo et al. (2007) tested strawberries in osmotic solutions of $60 \%(\mathrm{w} / \mathrm{w})$ sucrose and $60 \%(\mathrm{w} / \mathrm{w})$ sorbitol at $30^{\circ} \mathrm{C}$ for $1,2,4$, and $6 \mathrm{~h}$. They observed that solid gain steadily increased in both sorbitol and sucrose solutions, and then stabilized after 4 and $6 \mathrm{~h}$, respectively. Yet, most of the solid gains in glucose did not occur until after the second hour. Solid gains were also higher in fruit treated with sorbitol solution than with the sucrose solution. Shi et al. (1995) reported similar results when testing strawberries, but noticed water loss was much more rapid in the 60-90 min period than sugar gains. The high 
amount of water loss was due to high osmotic pressure reacting on the membrane of the fruit; however, the large size of the sucrose molecules impeded diffusion into the fruit.

\section{Agitation and Mixing}

Agitation and mixing influences mass transfer between osmotic solution and fruit. Typically, agitation promotes water loss when temperatures are less than $30^{\circ} \mathrm{C}$ and when viscosity of the solution is high. Eventually the effect of agitation will decrease until it has no effect on water loss (Tortoe et al. 2009). As Shi et al. (1995) noted in their study on apricots, pineapple, and strawberries, agitation can decrease the surface effects on fruit. However, gases in solution can adhere on the surface of the fruit, causing a boundary layer that impedes diffusion. Gases inside the fruit, solution, and boundary layer obstruct diffusion and reduce the rate of diffusion of water. To alleviate this issue, vacuum pressures are used to remove gases from solution and fruit, thereby increasing water transfer.

Mavroudis et al. (1998) studied the effect of agitation on apples using a 50\% sucrose solution at $20^{\circ} \mathrm{C}$ with impeller Re of $350,1000,2500,5000,10000,13000,16000$, and 18500. Turbulence occurs at a Re above 10000 when viscosity is higher. Water loss was higher at 16000 and 18500; however solid gain was not significantly affected. It appears as though agitation causes mass transfer to occur through convection from solution to fruit skin, and then by diffusion through fruit skin via diffusion within fruit. Tonon et al. (2007) studied the effect of process variables, including agitation, on osmotic dehydration of tomatoes. Solution compositions varied from $0 \%$ salt: $65 \%$ sucrose $(\mathrm{w} / \mathrm{w})$ to $10 \%$ salt: $55 \%$ sucrose $(\mathrm{w} / \mathrm{w})$ and agitation speeds of 0-1000 rotations per minute (rpms) at temperatures of $20-40{ }^{\circ} \mathrm{C}$. Agitation increased water loss, and with higher agitation speeds, the water mass transfer coefficient was increased. They explained these results using the dilution phenomena. Agitation restored the 
concentration difference between the fruit and solution, which allows for increased mass transfer. Though they saw increased water loss, they did not see any significant change in transfer of salt or sucrose. Tortoe et al. (2009) found similar results in their study on potato, banana, and two apple varieties. They used a solution of $0.5 \%$ sodium chloride in $40,50,60,70 \%$ sucrose at 55 ${ }^{\circ} \mathrm{C}$. They noted statistically minimal improvements in water loss but not for solid gains. Statistically significant increases in water loss and solid gain were seen in salt/sugar solutions with agitation compared to the same solution without agitation in all four sample types. Results were, again, attributed to the mixing of solution at the sample to solution interface.

\section{Fruit structure}

Biomaterial structure influences diffusion rates and mass transfer. Porosity and fruit ripeness are main contributors to this influence. Different fruits have different porosities or measure of spaces in the fruit. Porosity is also a fraction of the volume of voids over the total volume. In fruits, porosities can be measured optically with microscopes. Fruits with more pores tend to have faster water loss and solid gain. Shi et al. (1995) identified that fruits (pineapple, apricots, and strawberries) with differing porosities reacted differently when undergoing OD under vacuum and normal pressure. They determine that the pore sizes of pineapple tend to be around $8-9 \%, 5-6 \%$ for apricots, and 2-3\% for strawberries. They found that fruits with higher porosities, such as pineapple, have a higher water loss than fruits with lower porosities, such as strawberries. They attributed this effect to the number of pores. Additionally, the pores were filled with gases that could be removed during the vacuum pulse. However, Escriche et al. (2000) tested kiwis with a sucrose solution at $65{ }^{\circ}$ Brix and a grape juice concentrate at $63{ }^{\circ}$ Brix and 25,35 , and $45^{\circ} \mathrm{C}$ with a pulse vacuum time of $0,5,10$, and $15 \mathrm{~min}$. They reported that this response to pressure is due to lower porosity-fruits having a poor HDM contribution. The same 
response to pressure was observed by Gras et al. (2002) in evaluation of various vegetables (beetroot, carrot, eggplant, zucchini, mushroom, and oyster mushroom) with a pulsed vacuum for 5,10 , and $15 \mathrm{~min}$ and without a pulsed vacuum. Since riper fruits have higher sugar content than unripe fruits, the effectiveness of the hypertonic solution could be adversely influenced. Efficacy of mass transfer depends on differences in osmotic concentration; therefore, ripe fruits would need a higher concentration of osmotic solution to attain similar mass transfer rate compared to less ripe fruits (Panarese et al., 2012).

\section{Physical and Chemical Changes}

Many physical and chemical changes occur in fruits when solute and water fluxes occur resulting in a major change in cell structure. OD also causes plasmolysis in cells (Moreno et al., 2012). Plasmolysis is a process that occurs in cells during rapid water loss in which the cytoplasm pulls away from the cell wall. In OD, water loss from the fruit stimulates volume reduction, which causes the intercellular spaces to become collapsed and shrunken, and the cell membrane to become detached from the cell wall. The cell wall becomes distorted, which induces some mechanical stress. When membrane functionality is lost, exterior solutes are able to diffuse easily to other areas of the fruit tissues. Eventually the cell wall will relax and, with the pressure from the external solution, cell cavities will regain some shape and volume due to the impregnation (Gras et al., 2002).

Another potential alteration to consider is a change in color. Chiralt and Talens (2005) believe that increases in the refractive index of fruit tissues and degradation of pigments are the usual causes of any color changes. Moreno et al. (2012) also observed color changes in osmotically dehydrated fruit. In their study, they placed strawberries in a $65^{\circ}$ Brix solution for 5 $\mathrm{h}$ at 30,40 , and $50{ }^{\circ} \mathrm{C}$ using ohmic heating $(\mathrm{OH})$ and conventional heating. OD and VI were used 
with VI treatments having a 5 min vacuum pulse of $5 \mathrm{kPa}$. They found that clarity of color was increased in $\mathrm{OD}, \mathrm{OD}-\mathrm{OH}$, and VI-OH treated samples at 40 and $50{ }^{\circ} \mathrm{C}$ when compared with fresh. Chroma (purity or saturation) of the color was the color aspect most affected in strawberries, and was lower in VI and VI-OH treatments at 40 and $50{ }^{\circ} \mathrm{C}$. The loss in Chroma was linked to an increase in transparency due to a decrease in gases. When compared to fresh fruit, OD and OD-OH samples had higher hue values.

Rodrigues et al. (2003) found different results for chrome in papayas. In their study, papaya was tested in four types of solutions with different concentrations of sucrose, citric or lactic acid, and sodium lactate or calcium chloride and was in solution for up to $7 \mathrm{~h}$. During the first hour of the experiment, in solutions of $70^{\circ}$ Brix with lactic acid and sodium lactate at $50{ }^{\circ} \mathrm{C}$, $70{ }^{\circ}$ Brix with lactic acid and sodium lactate at $30{ }^{\circ} \mathrm{C}$, and $70{ }^{\circ}$ Brix with citric acid and sodium lactate at $30{ }^{\circ} \mathrm{C}$, luminosity (brightness) values were found to decrease and then slightly increase to statistically significant values. This trend was not seen in the solution of $50^{\circ} \mathrm{Brix}$ with lactic acid and calcium chloride at $50{ }^{\circ} \mathrm{C}$, instead, luminosity increased and with a decrease during the first hour. These differences in the results were attributed to formation of calcium pectate that intensifies whiteness. After $3 \mathrm{~h}$ of dehydration, chrome values increased and stabilized, apparently due to increased solid uptake and increased intracellular concentration.

During OD and VI, water loss may not be the only loss a fruit experiences. Concentrations of antioxidants, phenolic compounds, and other nutrients may be altered. NuñezMancilla et al. (2012) tested the effects on antioxidant, phenolic compound, and vitamin C content of strawberries by using a $40^{\circ}$ Brix osmotic solution and pulling pressures of 100, 200, 300, 400, and $500 \mathrm{MPa}$ for $10 \mathrm{~min}$. In all treatments, except for the $400 \mathrm{MPa}$ pressure, they found decreased antioxidant levels in the strawberries. At $400 \mathrm{MPa}$, they saw increased 
antioxidant levels were statistically significant when compared to untreated samples. They noted a different result for total phenolic content. For 100 and $200 \mathrm{MPa}$, phenolics were not significantly increased when compared to untreated samples; however, pressures of 300, 400, and $500 \mathrm{MPa}$ showed a statistically significant increase in the total phenolic compounds. They explained these differences in total phenolic content and antioxidants by stating that the antioxidants had increased extractability after samples were treated with higher pressures. Vitamin C was preserved with $98 \%$ retention levels in samples treated at 200, 400, and $500 \mathrm{MPa}$, though samples treated at 100 and $300 \mathrm{MPa}$ contained less Vitamin C when compared to untreated samples. The Vitamin $\mathrm{C}$ content variations could be explained by potential pressureinduced oxidative reactions catalyzed by certain enzymes, such as ascorbic acid oxidase.

Peiró et al. (2006) studied micronutrient flow during OD by placing grapefruit in an osmotic solution of $55^{\circ} \mathrm{Brix}$ for $3 \mathrm{~h}$ at $30^{\circ} \mathrm{C}$. They noted a loss of acids despite a similar $\mathrm{pH}$ for fresh and OD. In an ANOVA test, they showed that ascorbic acid losses were not statistically significant, though loss of citric acid was statistically significant between fresh and treated samples. When major minerals were examined, OD fruit experienced losses of calcium (28\%), magnesium (29\%), potassium (57\%), phosphorus (40\%), and sodium (59\%).

Peiró-Mena et al. (2007) also noted similar losses of citric acid and minerals in OD pineapple. In this study, pineapple was placed in a $55^{\circ}$ Brix solution for $2 \mathrm{~h}$ at $30^{\circ} \mathrm{C}$. As in the previous study, they observed a loss in citric acid (34\%), without a significant change in $\mathrm{pH}$. Calcium (59\%), magnesium (26\%), potassium (44\%), phosphorus (30\%), and sodium (41\%) were lost in the solution throughout the experiment. Stojanovic and Silva (2007) tested blueberries in a solution of $55^{\circ} \mathrm{Brix}$ at $21^{\circ} \mathrm{C}$ for 3 and $12 \mathrm{~h}$ and with and without high frequency ultrasound. After OD, berries were air-dried at $70{ }^{\circ} \mathrm{C}$ for $10 \mathrm{~h}$. At high frequency ultrasound for 3 
h, anthocyanins and phenolic compounds decreased by $42 \%$ and $44 \%$, respectively, when compared to a thawed sample. A 59\% loss of anthocyanins and phenolic compounds was observed in the $12 \mathrm{~h}$, no high frequency ultrasound group, while a $20 \%$ loss in anthocyanins and phenolic compounds was noted in the $3 \mathrm{~h}$, no high frequency ultrasound group. For this study, they found a significantly high correlation $(r=.9)$ between total phenolics and anthocyanins in the OD fruit. Phenolic and anthocyanin loss was increased further during air dehydration.

\section{Microbiology Concerns}

Despite the reduction of water activity $\left(\mathrm{A}_{\mathrm{w}}\right)$, food safety and contamination prevention are still major concerns. Decreasing $\mathrm{A}_{\mathrm{w}}$ alone is not regarded as adequate enough to assure a shelf-stable product. Gianotti et al. (2001) indicated that stability can be achieved by using other methods of preservation, such as canning, drying, or freezing. When multiple processes are used together in order to reduce and slow down microbial growth, the "hurdle concept" applies. Though osmotic dehydration and vacuum impregnation have many benefits, neither process reduces initial microbial load. Initial microbial load can be reduced through proper cleaning steps before OD or VI is applied. Therefore, the addition of other hurdles to help impede microbial growth is critically suggested.

In addition to initial microbial load of the fruit, yeast contamination is another major concern to shelf stability and safety. Contamination from yeast typically occurs if osmotic processes are conducted without air filtering systems. Yeasts can withstand a large range of temperatures; and if contamination does occur, fermentation of the solution could greatly affect not only the shelf stability, but also the flavor and appearance of the fruit (Dalla Rosa and Giroux 2001). Osmotic solution quality could also cause potential problems. As a way to reduce expenses, Moraga et al. (2011) evaluated the potential of reusing the OD solution. Cut grapefruit 
was placed in an osmotic solution of $55^{\circ}$ Brix at a temperature of $30{ }^{\circ} \mathrm{C}$ for $3 \mathrm{~h}$, with a vacuum treatment of 50 mbar for $10 \mathrm{~min}$ at the beginning of the experiment. Solution was reused for 5 OD cycles with either a mild heat treatment before each cycle, or without any type of heat treatment. Samples of fruit and solution were taken after 1, 3 and 5 OD cycles. After cycles 3 and 5 without any heat treatment, a steady increase in microbial content in the fruit was noted when compared to fresh cut grapefruit. After cycle 5, the solution without any heat treatment experienced a subsequent drop in shelf-life from 7-12 days to only 5 days. Albeit, after a mild heat treatment after every cycle, reconcentrated solution does have the potential to be reused.

\section{Industrial Application}

Consumers are demanding more wholesome and appetizing processed vegetables and fruits. OD has become an important process due to this demand, and increasing rate of diffusion and efficiency are important goals for OD. Since aims are to increase the rate and efficiency of mass transfer, VI has become a very practical addition to OD. VI also has great potential in improving food quality. VI is used to introduce solutions into food, so there is a potential that compounds like anti-microbial agents, nutritional ingredients, and certain enzymes could be added to the osmotic solution to enhance the product (Derossi et al. 2012). With the limited research on the effect of OD, VI, and PVOD on flavor, an opportunity exists to study the change in taste of various fruits treated with OD, VI, or PVOD.

Improving industrial processes is not the only goal of the food industry; decreasing product waste and increasing profit are crucial as well. Since there is a flux of nutrients to the osmotic solution, reuse of the solution for multiple OD cycles is of great interest. As shown above, Peiró et al. (2006) saw an increase in solution citric acid and mineral content after OD of grapefruit. With this finding, they proposed that it would be advantageous to use the solution as 
an ingredient in other food formulations. García-Martínez et al. (2002) also noted diffusion of mineral salts into the solution in their study on the potential of reusing the osmotic solution as an ingredient. To do this, they dehydrated kiwifruit in a solution of $55^{\circ}$ Brix with fruit to solution ratios of 1:20, 1:10, and $1: 5$ for $1 \mathrm{~h}$ at $30^{\circ} \mathrm{C}$. Osmotic solution was reused for up to $10 \mathrm{OD}$ cycles and was not reconcentrated, however fruit was replaced after every cycle. The fruit and solution were analyzed after cycles $0,1,2,3,6$, and 10. Final color of the fruit was not significantly affected. A flow of mineral salts to the solution was noted, making reuse of solutions in enriched foods seem appealing. They found no benefit to using a higher ratio (1:20) over a smaller one (1:5). Their results showed, that in the first ten cycles, the number of colonyforming units (CFU) was insignificant. However, Moraga et al. (2011) found different results in their study on grapefruit. In their study, they stated that the osmotic solution could only be used up to 5 cycles in grapefruit, and pasteurization between cycles was suggested. Result differences suggest that fruit type may affect how many cycles a solution can be reused, since fruits differ in $\mathrm{pH}$, sugar levels, and microbial content. Lower $\mathrm{pH}$ fruits may produce a solution that can be reused more than fruits with a higher $\mathrm{pH}$. The same would occur for fruits with less sugar than fruits with higher sugar content.

With every potential benefit, a challenge will generally present itself. Different osmotic solutions, temperatures, and pressures affect fruits in various ways. While one treatment may improve color and texture in one fruit, it could have the opposite effect on another. Due to the variability of each fruit and vegetable, research on treatment effects is needed before industrial application. Another difficulty could be finding food formulations that would be able to potentially use the spent osmotic solution. Though, if formulations were found, the nutrients in 
the solution could be destroyed through further processing, such as in candy making, thus failing to enhance nutrient content in the final product (Peiró et al., 2006; García-Martínez et al., 2002).

\section{Summary}

The opportunities for future research on this topic are numerous. There is an abundance of research on the effects of different factors on mass transfer rates; however, the effect on sensorial properties has not been sufficiently investigated. While improving transfer rates may help cut costs and product waste, flavor and texture could be negatively affected. Exploring this area further may enhance consumer satisfaction of dried fruits. The potential for use of spent osmotic solution in other food products should also be studied. Since there is a loss of important nutrients, such as minerals, antioxidants, and occasionally citric and ascorbic acids, into the osmotic solution, finding potential uses would greatly decrease product waste. Future research would need to include potential formulations and how processing protocols would affect different nutrients in the solution. 


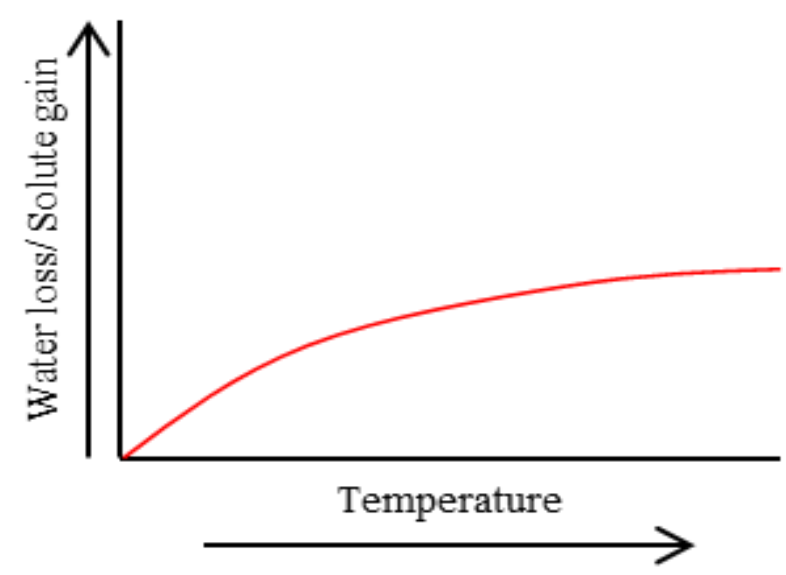

Figure 1: Effect of temperature on water loss/solute gain
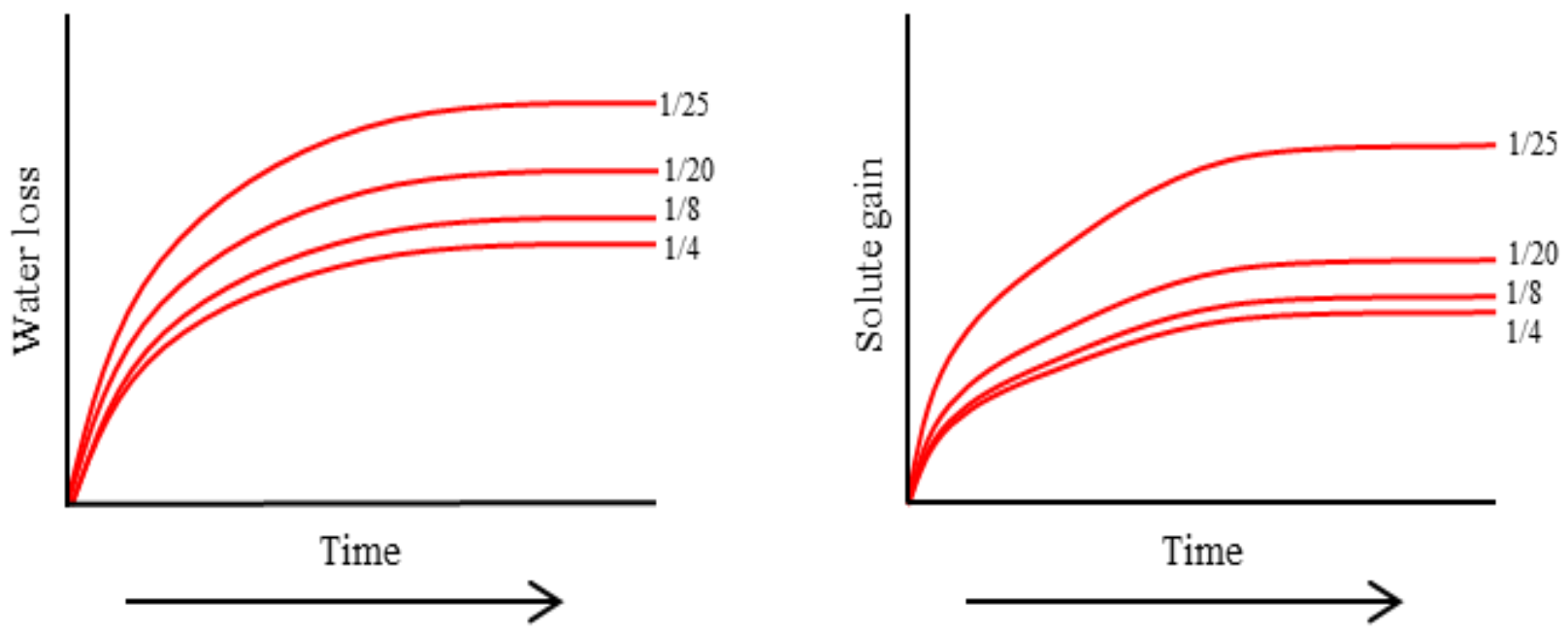

Figure 2: Effect of ratio of sample to solution on the water loss and solid gain. 


\section{References}

Barat, J.M., Fito, P., Chiralt, A. 2001. Modeling of simultaneous mass transfer and structural changes in fruit tissues. Journal of Food Engineering 49: 77-85.

Chiralt, A., Talens, P. 2005. Physical and chemical changes induced by osmotic dehydration in plant tissues. Journal of Food Engineering 67: 167-177.

Cruz, R.M.S., Vieira, M.C., Silva, C.L.M. 2009. The response of watercress (Nasturtium officinale) to vacuum impregnation: effect of and antifreeze protein type 1 . Journal of Food Engineering 95: 339-345.

Dalla Rosa, M., Giroux, F. 2001. Osmotic treatments (OT) and problems related to the solution management. Journal of Food Engineering 49: 223-236.

Derossi, A., De Pilli, T., Severini, C. 2012. The application of vacuum impregnation techniques in food industry. In Valdez, B. (Ed.), Scientific, Health and Social Aspects of the Food Industry Rijeka: InTech. Rijeka. Pp.:25-56.

Du, S.Y., Zhao, Y.H. 2001. New boundary conditions for the evaporating thin-film model in a rectangular micro channel. International Journal of Heat and Mass Transfer 54:36943701.

Escriche, I., García-Pinchi, R., Andrés, A., Fito, P. 2000. Osmotic dehydration of kiwifruit (Actinidia chinensis): fluxes and mass transfer kinetics. Journal of Food Process Engineering 23: 191-205.

Fito, P. 1994. Modelling of vacuum osmotic dehydration of food. Journal of Food Engineering 22:313-328.

Fito, P., Chiralt, A., Martínez-Monzó, J., Barat, J. 2002. Hydrodynamic mechanisms in plant tissues during mass transport operations. In: Welti-Chanes, J., Velez-Ruiz, J. F. (Eds.), Transport phenomena in food processing, Boca Raton, Florida. Pp.: 125-136.

İspir, A., Türk Toğrul, I. 2009. Osmotic dehydration of apricot: Kinetics and the effect of process parameters. Chemical Engineering Research and Design 87: 166-180.

García-Martínez, E., Martínez-Monzó, J., Camacho, M.M., Martínez-Navarrete, N. 2002. Characterisation of reused osmotic solution as ingredient in new product formulation. Food Research International 35: 307-313.

Gianotti, A., Sacchetti, G., Guerzoni, M.E., Dalla Rosa, M. 2001. Microbial aspects on shorttime osmotic treatment of kiwifruit. Journal of Food Engineering 49: 265-270. 
Giraldo, G., Talens, P., Fito. P., Chiralt, A. 2003. Influence of sucrose solution concentration on kinetics and yield during osmotic dehydration of mango. Journal of Food Engineering 58: $33-43$.

Gras, M., Vidal-Brotóns, D., Betoret, N., Chiralt, A., Fito, P. 2002. The response of some vegetables to vacuum impregnation. Innovative Food Science and Emerging Technologies 3: 263-269.

Martin-Esparza, E., Gonzalez-Martinez, C. 2008. Osmotic dehydration -Vacuum impregnation of fruit. In Viera, M.M.C., Ho, P. (Eds.), Experiments in Unit Operations and Processing of Foods. Pp.:47-51.

Martínez-Valencia, B.B., Abud-Archilla, M., Ruiz-Cabrera, M.A., Grajales-Lagunes, A., Dendooven, L., Ovando-Chacón, S.L., Gutiérrez-Miceli, F.A. 2011. Pulsed vacuum osmotic dehydration kinetics of melon (Cucumis melo L.) var. cantaloupe. African Journal of Agricultural Research 6: 3588-3596.

Mavroudis, N.E., Gekas, V., Sjöholm, I. 1998. Osmotic dehydration of apples- effects of agitation and raw material characteristics. Food Engineering 35: 191-209.

Moraga, M.J., Moraga, G., Martínez-Navarrete, N. 2011. Effect of the re-use of the osmotic solution on the stability of osmodehydro-refrigerated grapefruit. Food Science and Technology 44: 35-41.

Moreno, J., Simpson, R., Baeza, A., Morales, J., Muñoz, C., Sastry, S., Almonacid, S. 2012. Effect of ohmic heating and vacuum impregnation on the osmodehydration kinetics and microstructure of strawberries (cv. Camarosa). Food Science and Technology 45:148154.

Nuñez-Mancilla, Y., Pérez-Won, M., Uribe, E., Vega-Gálvez, A., Di Scala, K. 2012. Osmotic dehydration under high hydrostatic pressure: Effects on antioxidant activity, total phenolic compounds, vitamin C and colour of strawberry (Fragaria vesca). Food Science and Technology 1-6.

Panarese, V., Tylewicz, U., Santagapita, P., Rocculi, P., Dalla Rosa, M. 2012. Isothermal and differential scanning calorimetries to evaluate structural and metabolic alterations of osmo-dehydrated kiwifruit as a function of ripening stage. Innovative Food Science Emerging Technologies.

Peiró, R., Dias, V.M.C., Camacho, M.M., Martínez-Navarrete, N. 2006. Micronutrient flow to the osmotic solution during grapefruit osmotic dehydration. Journal of Food Engineering 74:299-307. 
Peiró-Mena, R., Camacho, M.M., Martínez-Navarrete, N. 2007. Compositional and physicochemical changes associated to successive osmodehydration cycles of pineapple (Ananas comosus). Journal of Food Engineering 79:842-849.

Rizzolo, A., Gerli, F., Prinzivalli, C., Buratti, S., Torreggiani, D. 2007. Headspace volatile compounds during osmotic dehydration of strawberries (cv Camarosa): Influence of osmotic solution composition and processing time. LWT-Food Science and Technology 4: 529-535.

Rodrigues, A.C.C., Cunha, R.L., Hubinger, M.D. 2003. Rheological properties and colour evaluation of papaya during osmotic dehydration processing. Journal of Food Engineering 59:129-135.

Shi, J., Maguer, M.L. 2002. Mass transfer in cellular material at solid-liquid contacting interface. LWT-Food Science and Technology 36:3-11.

Shi, J., Maguer, M.L. 2002. Osmotic dehydration of foods: Mass transfer and modeling aspects. Food Reviews International. 18: 305-335.

Shi, X.Q., Fito, P., Chiralt, A. 1995. Influence of vacuum treatment on mass transfer during osmotic dehydration of fruits. Food Research International 28: 445-454.

Singh, B., Panesar, P.S., Nanda, V., Kennedy, J.F. 2010. Optimisation of osmotic dehydration process of carrot cubes in mixtures of sucrose and sodium chloride solutions. Food Chemistry 123:590-600.

Stojanovic, J., Silva, J.L. 2007. Influence of osmotic concentration, continuous high frequency ultrasound and dehydration on antioxidants, color and chemical properties of rabbiteye blueberries. Food Chemistry 101:898-906.

Taylor, R., Krishna, R. "Fick's Law." Multicomponent Mass Transfer. John Wiley and Sons, 1993.

Toledo, R.T. 2007. Fundamentals of Food Process Engineering (Third edition). Springer, New York, NY.

Tonon, R.V., Baroni, A.F., Hubinger, M.D. 2007. Osmotic dehydration of tomato in ternary solutions: Influence of process variables on mass transfer kinetics and an evaluation of the retention of carotenoids. Journal of Food Engineering 82: 509-517.

Tortoe, C., Orchard, J., Beezer, A. 2009. Effect of agitation and antagonism between sucrose and sodium chloride on mass transfer during osmo-dehydration in plant materials. International Food Research Journal 16: 521-530. 
Welti-Chanes, J., Mújica-Paz, H., Valdez-Fragoso, A., Leon-Cruz, R. 2002. Fundamentals of mass transport. In: Welti-Chanes, J., Velez-Ruiz, J. F. (Eds.), Transport Phenomena in Food Processing, Boca Raton, FL. Pp.: 3-24. 


\section{Chapter 2: Effect of Processing Parameters on Dried Blueberry Yield and Water Activity}

\section{Introduction}

As the leading world producer of blueberries, the United State produced 564.4 million pounds of blueberries with approximately half going to further processing (Geisler, 2012). Processed blueberries end up in a number of products such as cereals, muffin mixes, ice creams, and even by themselves as a dried fruit. With this large need for the United States' second most valuable berry crop, efficient processing methods are vital to fulfilling consumer demand. One method of great interest is osmotic dehydration.

Osmotic dehydration (OD) is a method that helps to remove water from foods (especially in fruits such as blueberries). OD begins by placing fruit samples into a hypertonic solution, which causes a higher concentration gradient outside of the fruit. Diffusion of water from the fruit is countered with a concurrent diffusion of the solutes from the solution. As described by Shi and Maguer (2003) when a sample is placed in a hypertonic solution (a solution where the total molar concentration of all dissolved solute particles is greater than that of another solution, or greater than the concentration in the fruit), the first layer of cells at the surface exhibits water loss. A gradient then occurs between the first and second layer of cells. This second layer begins to lose water into the first layer, where the first layer again loses water to the osmotic solution. This process repeats itself until the middle layer begins to lose water to the previous layer, which eventually leads to diffusion equilibrium at the end of the OD process. Unfortunately, semipermeable membranes are not perfectly selective. One disadvantage of OD is that nutrients present in the food can also be diffused with the water into the solution, which modifies the nutritional and organoleptic features of the fruit (İspir and Türk Toğrul 2009). 
Another process of interest is vacuum impregnation (VI). VI is achieved through the decrease of external pressure on the fruit. Since there is a higher pressure inside the fruit, liquids and gases that are inside begin to migrate out of the fruit, creating void space inside the cells. External pressure is raised back up to atmospheric pressure, causing the external solution to impregnate the fruit. Other goals of using VI are to enhance the nutritional and functional components of fruit, and to help reduce microbial growth and decomposition (Derossi et al. 2012).

Putting the OD and VI together forms a process called pulsed vacuum osmotic dehydration (PVOD). The PVOD technique involves immersing fruit into a hypertonic solution and decreasing the external pressure for a short time followed by a relatively longer OD interval at atmospheric pressures (Escriche et al., 2000). According to Fito et al. (2002), hypertonic solution enters the pores of the fruit through the hydrodynamic mechanism (HDM). HDM is a phenomenon that occurs when a porous solid is submerged in a liquid. The gas inside the solid's pores is compressed, while the external liquid enters the pores with the gas compression. Mass transfer rate and solid-liquid interface area are increased, which causes a decrease in the water activity of fruit due to water leaving the fruit and solutes migrating into the fruit. When there is no pressure change, impregnation will occur mainly from capillary pressure, which is the difference in pressure across the fruit skin (Fito et al. 2002). Though there is less moisture in the fruit, color and texture attributes are very comparable to fresh fruit due to less damage to the cellular structures (Escriche et al. 2000).

While quality is an important aspect, food safety and microbial contamination are other major concerns for any product, processed or fresh. While OD reduces water content significantly, water activity $\left(\mathrm{A}_{\mathrm{w}}\right)$ may still not be low enough to prevent mold or yeast growth. 
Though OD and VI have many benefits, they are only bacteriostatic and not bactericidal. As stated by Gianotti et al. (2001), stability can be achieved by adding other methods of preservation, such as canning, drying, or freezing. When multiple antimicrobial processes are simultaneously applied in order to reduce microbial growth, it is referred to as "hurdle concept". Therefore, the addition of other hurdles such as conventional drying to further lower water activity to help impede microbial growth is critical.

To maintain product safety, it is very important to understand the PVOD process parameters for specific fruit that control diffusion; and therefore, affect sugar intake and water loss. Optimized diffusion will result in an energy efficient process; and thus, will present practical benefits to the industry. To increase product yield and decrease water activity, osmotic dehydration and pulsed-vacuum osmotic dehydration can be applied to maximize water removal before final drying. Therefore, the objective of this study was to characterize the effect of PVOD process parameters (vacuum, osmotic solution temperature and concentration, and treatment duration) on yield and final water activity $\left(\mathrm{A}_{\mathrm{w}}\right)$ of dried blueberries.

\section{Materials and Methods}

\section{Raw Material and Preparation of Osmotic Solution}

Frozen, scarified blueberries (Michigan) grown in 2012 were purchased from Stokes Blueberries Freshpro, Inc. Blueberries were stored in a freezer at $-22^{\circ} \mathrm{C}$. The day prior to testing, berries were weighed out into $500 \mathrm{~g}$ bags and placed back into the freezer.

Osmotic solutions were prepared the day before with predetermined quantities of Kroger brand granulated sugar in distilled, deionized water. Distilled, deionized water was used as a method standard. Solutions were heated until sugar was dissolved. Solutions were separated into $1500 \mathrm{~g}$ amounts then stored in a refrigerator at $4^{\circ} \mathrm{C}$. 


\section{Experimental Design}

A $2 * 2 * 2 * 3$ Factorial Design with 3 replications was used: $2{ }^{\circ}$ Brix Variations

( $45^{\circ}$ Brix $/ 65^{\circ}$ Brix), 2 Vacuum Variations (No Vacuum/ 50 mbar for 15 minutes), 2 Temperature Variations $\left(25^{\circ} \mathrm{C} / 50^{\circ} \mathrm{C}\right)$, and 3 Time Variations $(180,240,300$ minutes). The fruit to solution ratio was maintained at $1: 3 \mathrm{~g} / \mathrm{g}$.

\section{Osmotic Dehydration and Vacuum Pressure Procedure}

Figure 4 shows the general set-up for PVOD. The vacuum chamber was a metal canister from a vacuum tumbler (Pepco Machines Inc.) and the osmotic dehydration chamber was a plastic, 1 gallon canister (Mainstays). In vacuum treated units, pressure was drawn for 15 minutes with a vacuum generator (GAST). To accounts for time differences, the no-vacuum units were placed beside the vacuum chamber for 15 minutes. After 15 minutes, all containers were placed into an incubator (Lab-Line Imperial III) on a shaker plate (Gyrotory Shaker-Model G2) for OD. The agitation speed of the shaker plate was $100 \mathrm{rpm}$.

\section{Conventional Dehydration Procedure}

Before and after experiments, weight was recorded with a basic scale (Mettler Toledo PM2000), $\mathrm{pH}$ was recorded using a $\mathrm{pH}$ meter (Corning $\mathrm{pH} / \mathrm{Ion}$ Analyzer 350 ), and ${ }^{\circ} \mathrm{Brix}$ was recorded with a digital refractometer (Reichert AR200). Blueberries were weighed again and conventionally dehydrated in a Food Dehydrator (Parallexx Excalibur) for 390 minutes at $57.2^{\circ} \mathrm{C}$. We chose 390 minutes so that the berries would be above at least $0.600 \mathrm{~A}_{\mathrm{w}}$. Typically, lower $A_{w}$ are desired but we did not want the berries completely desiccated. Trays were rotated every other hour. After conventional dehydration, weights were again taken and $A_{w}$ was measured using an $\mathrm{A}_{\mathrm{w}}$ meter (Decagon Devices AquaLab 4TE). 


\section{Calculations and Statistical Analysis}

Weight change was determined by subtracting the initial weight of the blueberries by the weight of the blueberries after OD. Change in sugar concentration was determined similarly by subtracting the initial ${ }^{\circ}$ Brix of the blueberries by the ${ }^{\circ}$ Brix of the blueberries after OD. Percent yield after OD was measured by dividing weight of blueberries after OD by the weight of the blueberries before OD and multiplying by 100 . Percent yield after conventional drying (CD) was measured by dividing the weight of blueberries after $\mathrm{CD}$ by the weight of the blueberries before $\mathrm{CD}$ and multiplying by 100. 2 different yield measurements were used because fruit was removed for testing between $\mathrm{OD}$ and CD steps.

Data were analyzed using JMP and SAS software (JMP®, Version Pro 11, SAS Institute Inc., Cary, NC, Copyright $\odot 2013$; SAS ${ }^{\circledR}$, Version 9.3, SAS Institute Inc., Cary, NC, Copyright (O2002-2010). Significance criterion alpha for all tests was 0.05. Analysis of variance (ANOVA) was performed on a $2 \times 2 \times 2 \times 3\left[{ }^{\circ} \mathrm{Brix}(45,65)\right.$; Temperature $\left(25^{\circ} \mathrm{C}, 50^{\circ} \mathrm{C}\right)$; Vacuum $(0 \mathrm{mbar}, 50$ mbar); Time (180, 240, 300 minutes)] factorial with 3 replications to indicate the effects of different osmotic dehydration treatments on weight change, sugar change, percent yield after OD, percent yield after conventional dehydration, and $A_{w}$. Main ANOVA was followed by Tukey-Kramer multiple comparison procedure (with adjustments for multiple comparisons) on least square means. Variables were detected to not be normally distributed (by Shapiro-Wilk W Test) and were log transformed.

\section{Results and Discussion}

\section{Fruit Weight Change}

ANOVA showed significant interaction between of solution ${ }^{\circ}$ Brix and temperature on blueberry weight change $(\mathrm{p}<0.005)$. Comparing the $45^{\circ} \mathrm{Brix} / 25^{\circ} \mathrm{C}$ treatment with the 
$65^{\circ} \mathrm{Brix} / 25^{\circ} \mathrm{C}$ one can see a significant difference in weight loss $(\mathrm{p}=0.0036)$ with the $45^{\circ} \mathrm{Brix} / 25^{\circ} \mathrm{C}$ treatment losing more weight than the latter (Fig 4). This suggests that sugar content of the solution does affect how much weight is lost when temperature is constant. However, weight loss can be seen to increase when $65^{\circ} \mathrm{Brix} / 25^{\circ} \mathrm{C}$ and $65^{\circ} \mathrm{Brix} / 50^{\circ} \mathrm{C}$ combinations are compared $(\mathrm{p}=0.0001)$. This result may be attributed to more efficient thawing. İspir and Türk Toğrul (2009) observed that solution concentration and temperature are directly linked to the rate of solid gain and water on apricots; however they did not see a rise in weight change with an increase in temperature.

\section{Change in Blueberry Sugar Content}

As shown in Figure 5, solution concentration was shown to significantly affect blueberry sugar content $(\mathrm{p}<0.0001)$. Higher solution concentration $\left(65^{\circ} \mathrm{Brix}\right)$ was shown to increase blueberry sugar content by $62 \%$ when compared to the sugar content of blueberries in the lower concentration solution $\left(45^{\circ}\right.$ Brix $)$.

Time was also shown to significantly affect blueberry sugar content, with longer times showing higher sugar content ( $\mathrm{p}<0.0001$, Fig 6$)$. Blueberry sugar content increased by 13.03 , 17.29 , and $17.68^{\circ}$ Brix in 180,240 , and 300 minutes, respectively. This effect can be seen most between 180 and 240 minutes, and 180 and 300 minutes ( $\mathrm{p}=0.0001$, and $\mathrm{p}<0.0001$, respectively). Between 240 and 300 minutes there is no significant difference, which was not expected as longer times should produce higher sugar content. At 300 minutes, diffusive flux seems to greatly slow down which could be due the concentration gradient being too low to maintain the rapid flux that we saw in the 180-240 minute interval. Moreno et al. (2012) also noted that samples reached water loss equilibrium at 240 minutes and solid gain equilibrium at 180 minutes in strawberries. For the blueberries in this experiment, a significant increase in sugar content was 
noted between 180 and 240 minutes. Though slightly different than Moreno et al. (2012), reaching sugar equilibrium is still a plausbile cause for this plateau. Another suggestion was made by Giraldo et al. (2003) that, at a $65^{\circ}$ Brix treatment, a decrease in solid gain was observed in line with process time. They attributed this to an explusion of solution that was originally diffused by capillary forces from the pores when external cells lost water causing the intercellular cells to collapse.

\section{Yield after OD Blueberries}

ANOVA showed a significant interaction between solution concentration and temperature on yield after OD ( $\mathrm{p}=0.0001$, Fig 7). Significant differences can be seen in comparisons between $45^{\circ} \mathrm{Brix} / 25^{\circ} \mathrm{C}$ and $65^{\circ} \mathrm{Brix} / 25^{\circ} \mathrm{C}$, and $65^{\circ} \mathrm{Brix} / 25^{\circ} \mathrm{C}$ and $65^{\circ} \mathrm{Brix} / 50^{\circ} \mathrm{C}$ $\left(\mathrm{p}=0.0032\right.$ and $\mathrm{p}=0.0001$, respectively). The first comparison between $45^{\circ} \mathrm{Brix} / 25^{\circ} \mathrm{C}$ and $65^{\circ} \mathrm{Brix} / 25^{\circ} \mathrm{C}$ suggests that solution concentration does increase yield when paired with temperature. The second comparison between $65^{\circ} \mathrm{Brix} / 25^{\circ} \mathrm{C}$ and $65^{\circ} \mathrm{Brix} / 50^{\circ} \mathrm{C}$ suggests that when concentration is high, temperature may increase water loss which may impede flux of sugar into the fruit.

\section{Yield after CD Blueberries}

Solution concentration, temperature, and time were all shown to significantly affect percent yield after $\mathrm{CD}(\mathrm{p}<0.0001, \mathrm{p}=0.0004, \mathrm{p}<0.0001)$. Figure 8 shows the effect of solution concentration on the yield. A significant increase in percent yield can be seen in the higher solution concentration. Larger blueberry sugar content is responsible for this difference.

Higher temperature was also shown to increase yield of the final product when compared to the lower temperature in Figure 9. This tends to contradict the results for percent yield after OD, as lower temperature produced a higher percent yield (84.4\%). Differences between these 
findings may be attributed to increased, though not significant, sugar gains in the higher temperatures.

Longer times (240, 300 minutes) were shown to increase final yield as shown in Figure 10. Since longer times allow for longer sugar transfer, blueberries in the 240 and 300 minute groups should have a higher sugar concentration, thus increasing the final product yield. Significant differences could be seen between the 180 and 300 minutes group $(\mathrm{p}<0.0001)$, and between the 240-300 minute groups ( $\mathrm{p}=0.0015$ ), however no significance was found between 180 and 240 minute groups $(\mathrm{p}=0.3622)$, which shows incomplete OD.

Figure 11 shows that vacuum was not significant in affecting yield after conventional drying. Yields were expected to significantly increase with the vacuum pressure. A small increase was noted but the rise was not enough to consider. This could be due to a plasmolysis effect happening inside the fruit, thereby damaging the cell walls to the point where they could not hold sugar.

\section{Water Activity}

$A_{w}$ seems to be affected by an interaction between solution concentration and temperature, as shown in figure $12(\mathrm{p}=0.0210)$. The most notable comparison is between $45^{\circ} \mathrm{Brix} / 25^{\circ} \mathrm{C}$ and $65^{\circ} \mathrm{Brix} / 25^{\circ} \mathrm{C}(\mathrm{p}=0.0370)$. This shows that both solution concentration and temperature have significant combined effects on $A_{w}$. Another point to note is the sudden increase in $\mathrm{A}_{\mathrm{w}}$ between the $65^{\circ} \mathrm{Brix} / 25^{\circ} \mathrm{C}$ and $65^{\circ} \mathrm{Brix} / 50^{\circ} \mathrm{C}$. A number of unknown reasons could cause this discrepancy such as a variation in placement in the dehydrator or lower sugar gain in the $65^{\circ} \mathrm{Brix} / 50^{\circ} \mathrm{C}$. Again, as stated by Giraldo et al. (2003), at $65^{\circ}$ Brix the impregnated sugar solution could have been expelled out of the fruit pores. 
In figure 13, vacuum pressure was shown to not significantly affect final $A_{w}$. Vacuum pressure was expected to produce a lower $A_{w}$ due to increased sugar gains, however only a small, insignificant decrease in $\mathrm{A}_{\mathrm{w}}$ was noted in the vacuum treatments.

\section{Conclusion}

In this study, vacuum pressure was not shown to significantly affect mass transfer in blueberries during OD. The most significant factors were shown to be higher solution concentration, longer time, and higher temperature. The yield of the final, conventionallydehydrated product was shown to be most affected by increasing these three factors. Based on the results found, a temperature of $50^{\circ} \mathrm{C}$, a solution concentration of $65^{\circ} \mathrm{Brix}$, and times above 4 hours would be best suited for blueberries.

\section{Implications}

Food safety and microbial contamination are still major concerns despite the reduction of water availability. While improving transfer rates may help cut costs and product waste, flavor and texture could be negatively affected. Exploring this area further could help enhance consumer satisfaction with the product. Further research will need to be done on how fresh blueberries perform when compared to frozen. Effect of fructose on mass transfer will also be addressed. Since there is a loss of important chemicals, such as minerals, antioxidants, and occasionally citric and ascorbic acids, into the osmotic solution, finding potential uses would greatly decrease product waste. Research would need to include potential formulations and how processing in the formulations would affect the different nutrients in the solution. Capability of utilizing used osmotic solution in other food products should also be studied. 


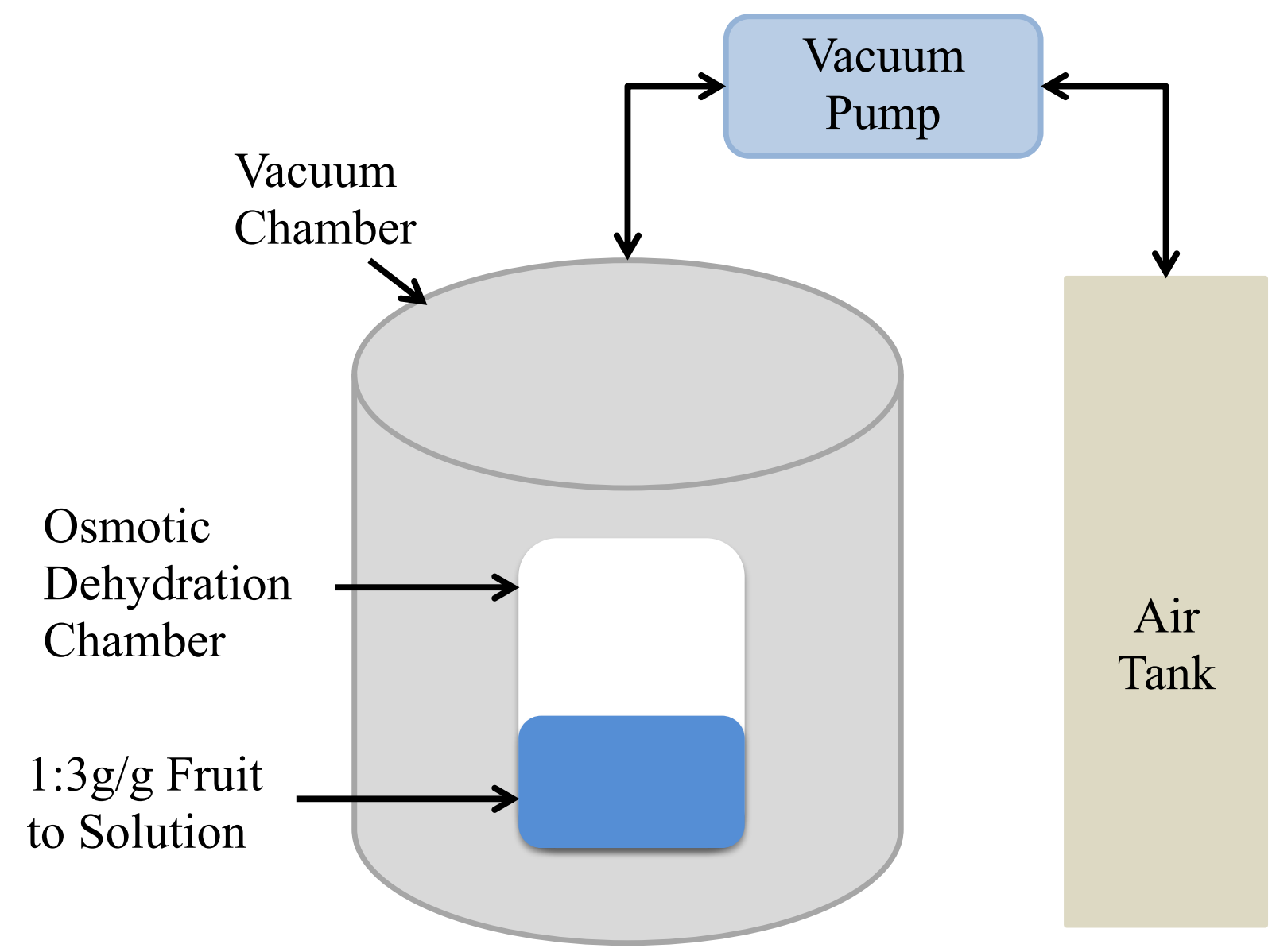

Figure 3: Schematic of the Pulsed Vacuum Osmotic Dehydration Apparatus. 


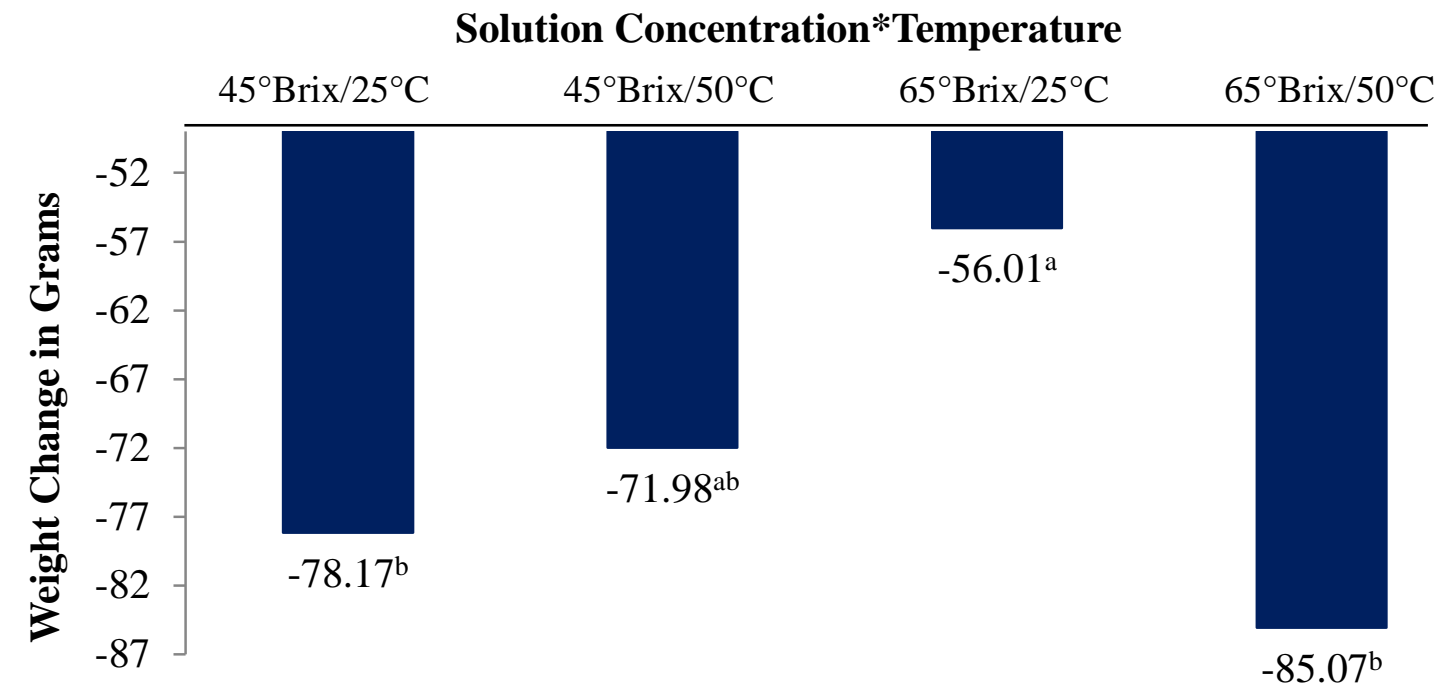

Figure 4: Effect of solution concentration and temperature on blueberry weight change.

${ }^{\mathrm{ab}} \mathrm{p}<0.05 ; \mathrm{SEM}=4.31$

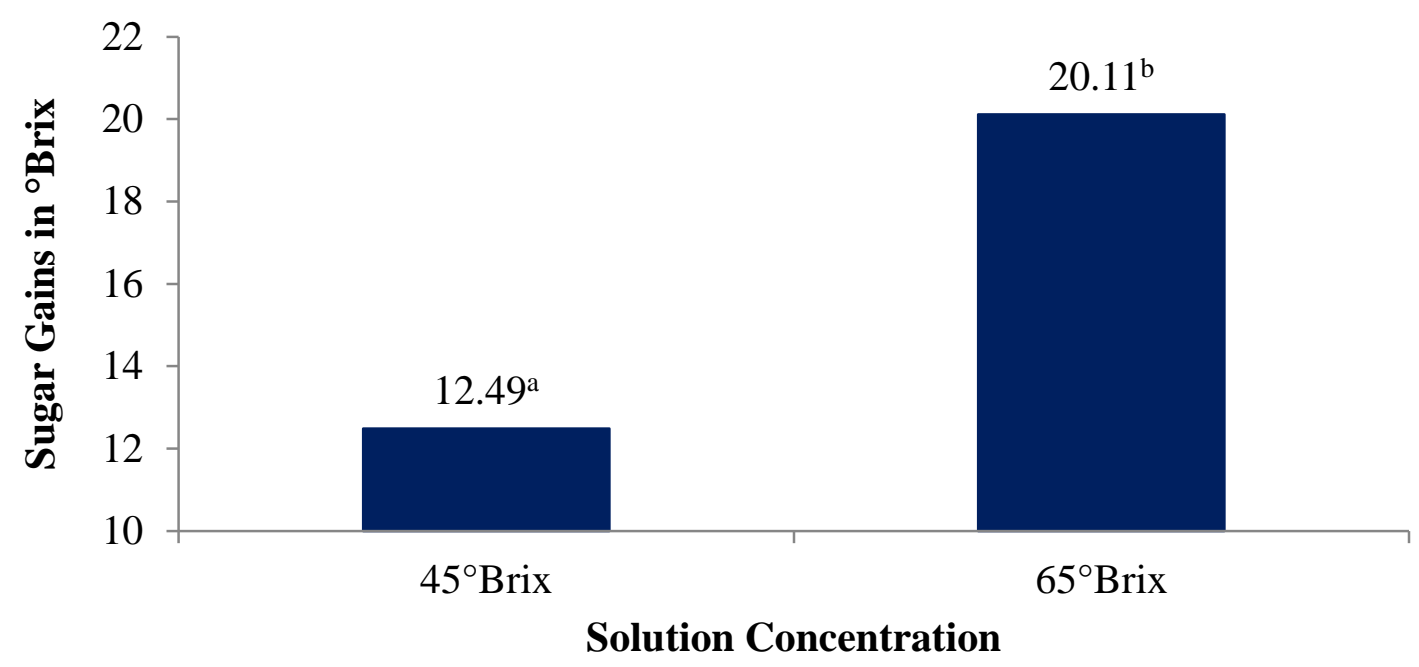

Figure 5: Effect of solution concentration on

blueberry sugar gains

${ }^{\mathrm{ab}} \mathbf{p}<0.0001 ;$ SEM=1.04 


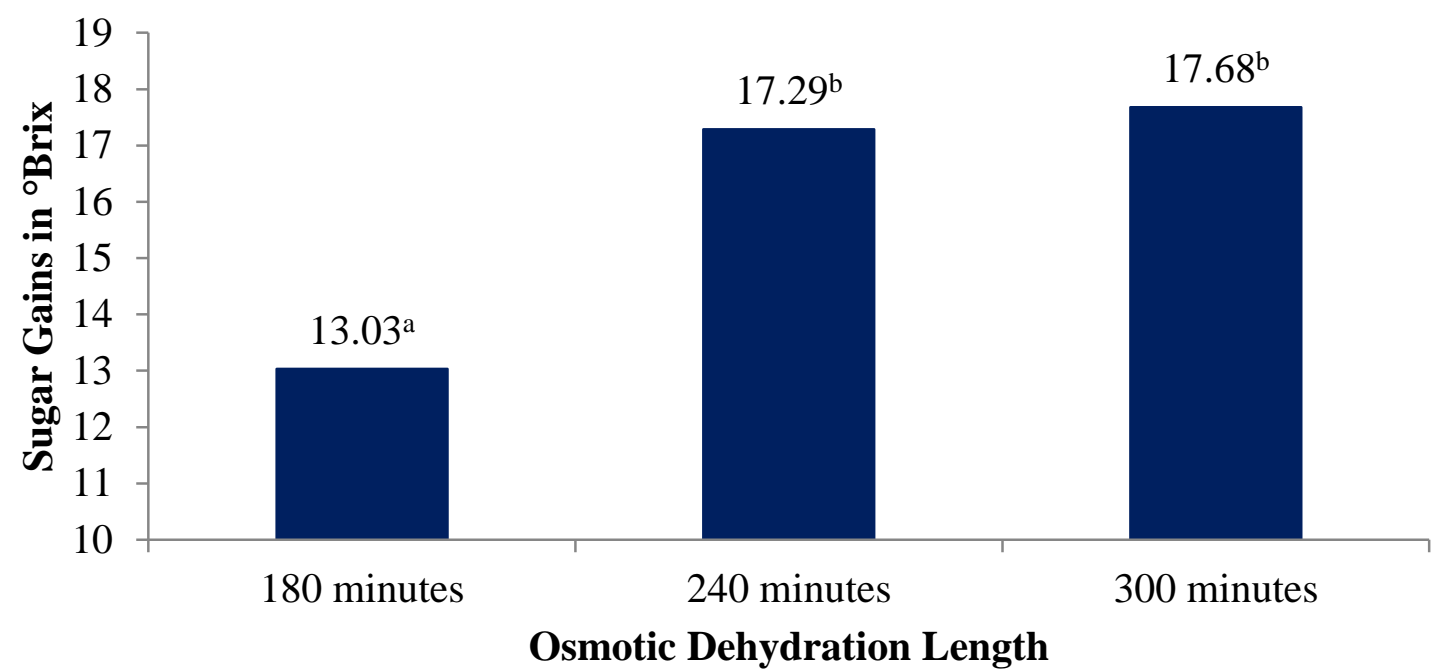

Figure 6: Effect of time on blueberry sugar gains.

${ }^{\mathrm{ab}} \mathbf{p}<0.0001 ; \mathrm{SEM}=1.05$

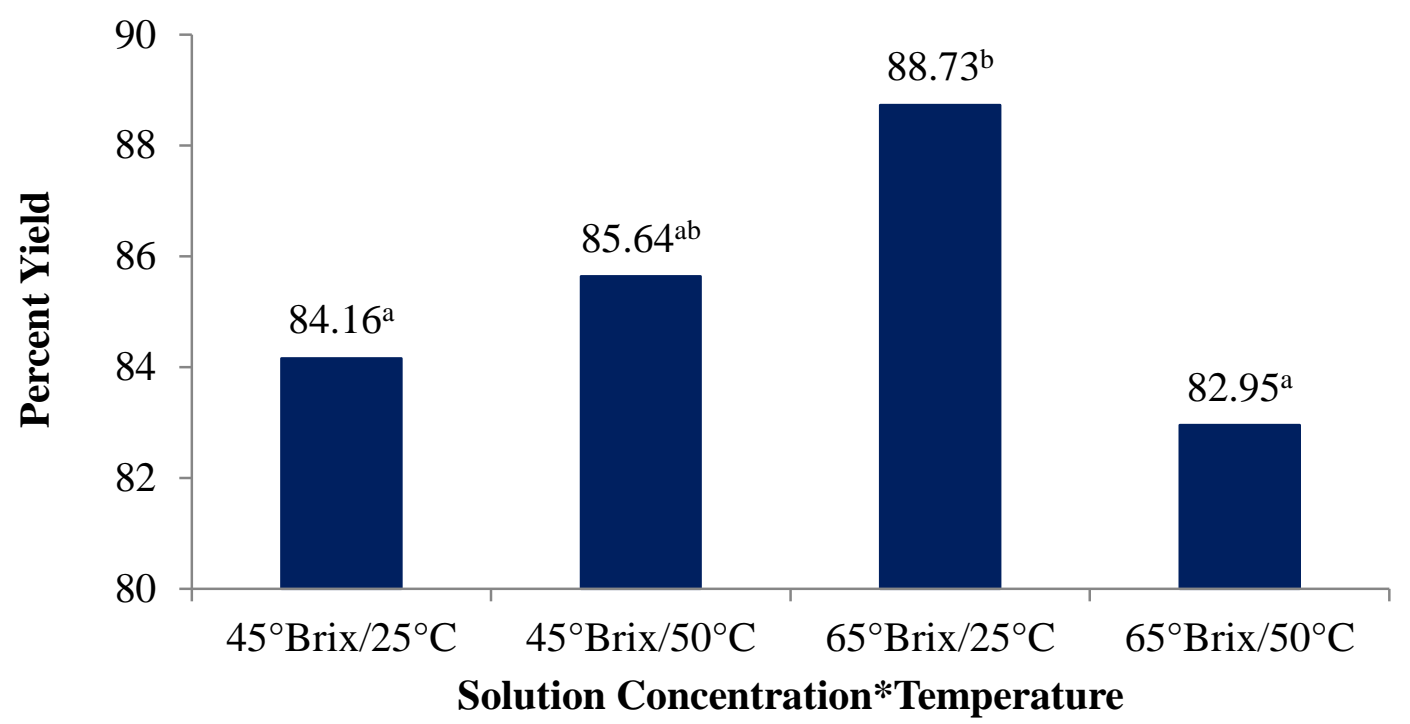

Figure 7: Effect of solution concetration and temperature on percent yield after osmotic dehydration.

${ }^{a b} \mathbf{p}<0.003 ;$ SEM=1.01 


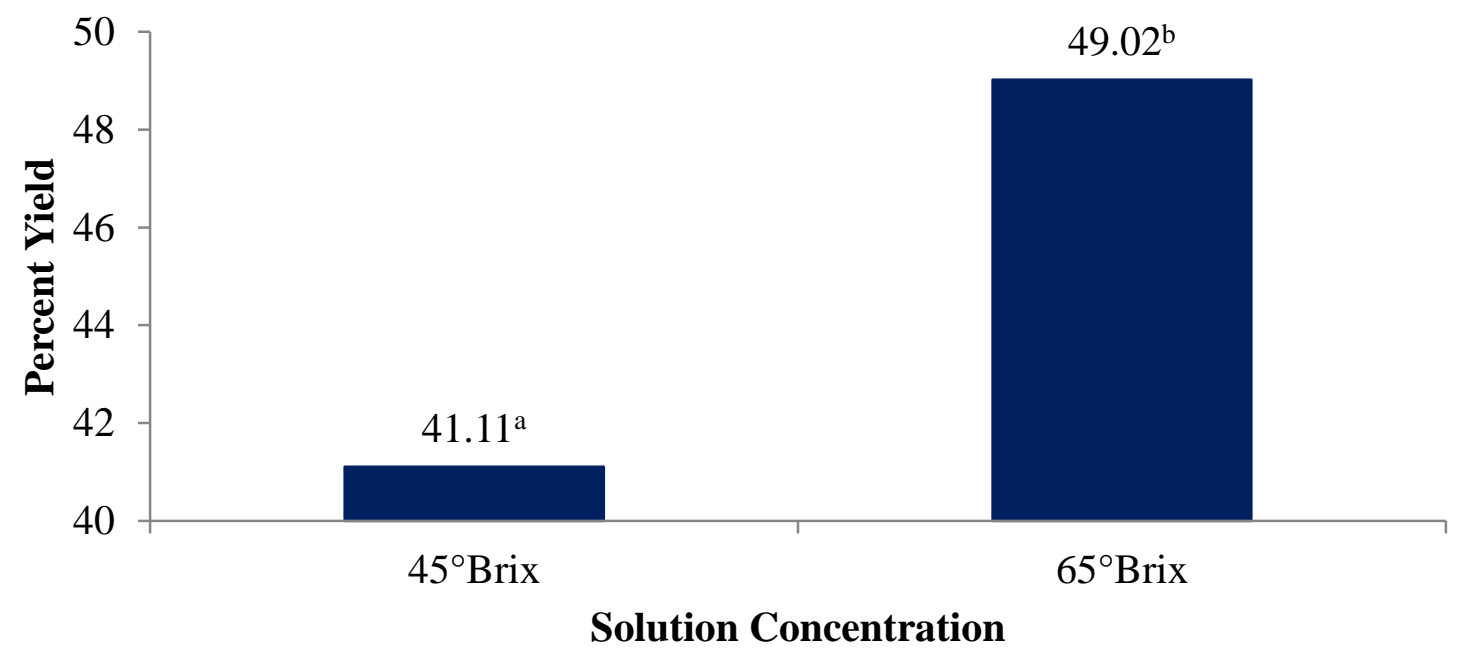

Figure 8: Effect of solution concentration on percent yield after conventional drying. ${ }^{a b} \mathbf{p}<0.0001 ;$ SEM=1.01

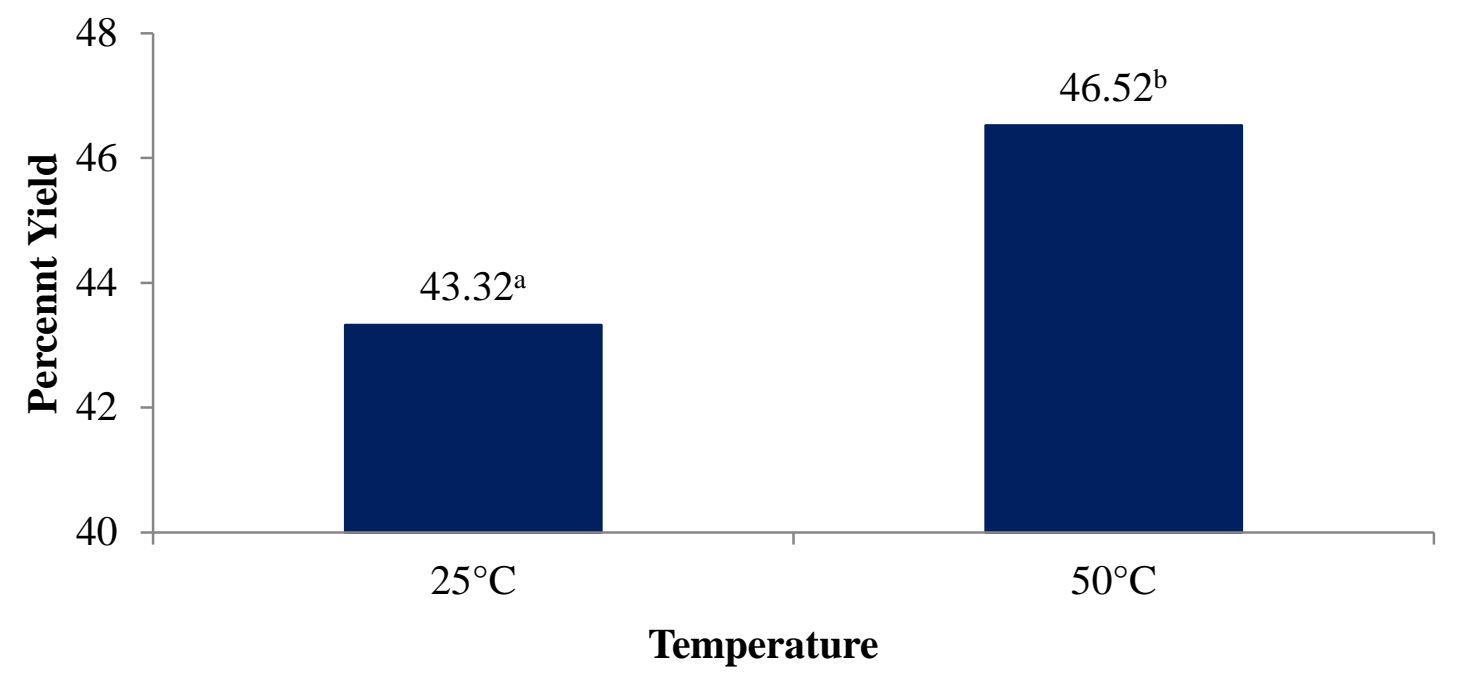

Figure 9: Effect of temperature on percent yield after conventional dehydration.

${ }^{\mathrm{ab}} \mathbf{p}<0.0004 ; \mathrm{SEM}=1.01$ 


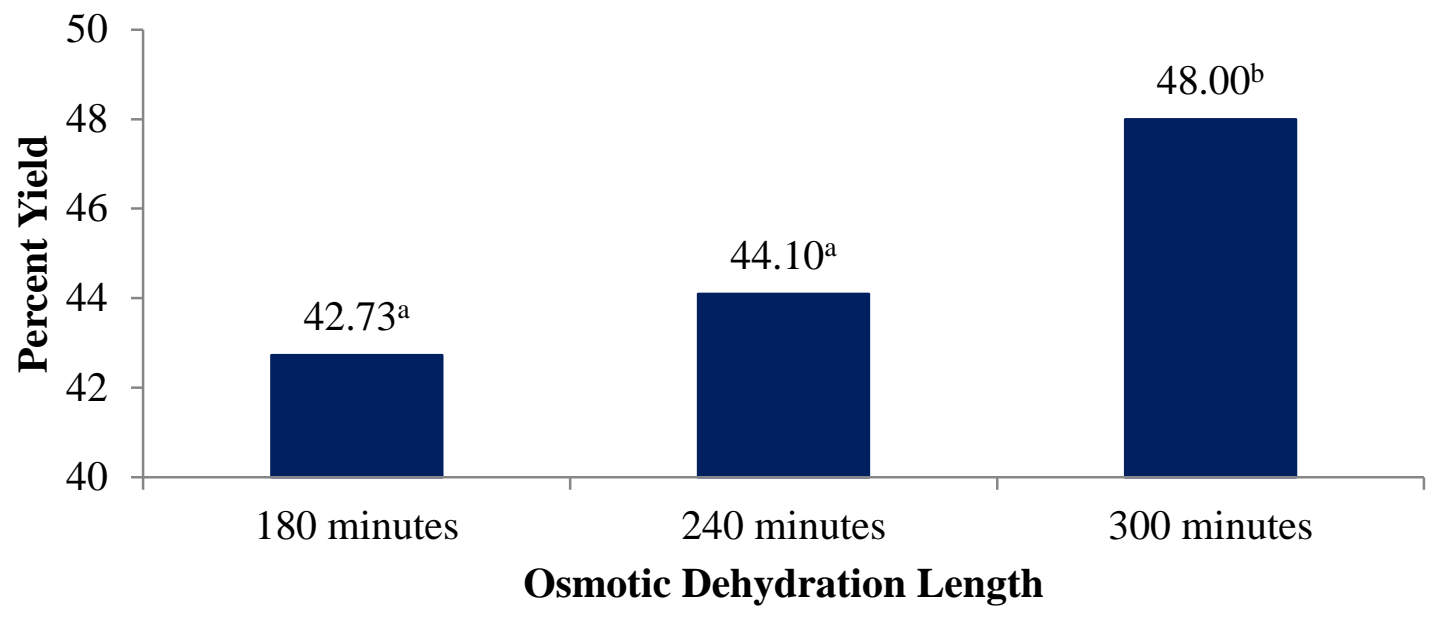

Figure 10: Effect of time on percent yield after conventional dehydration.

${ }^{a b} \mathbf{p}<0.002 ;$ SEM $=1.02$

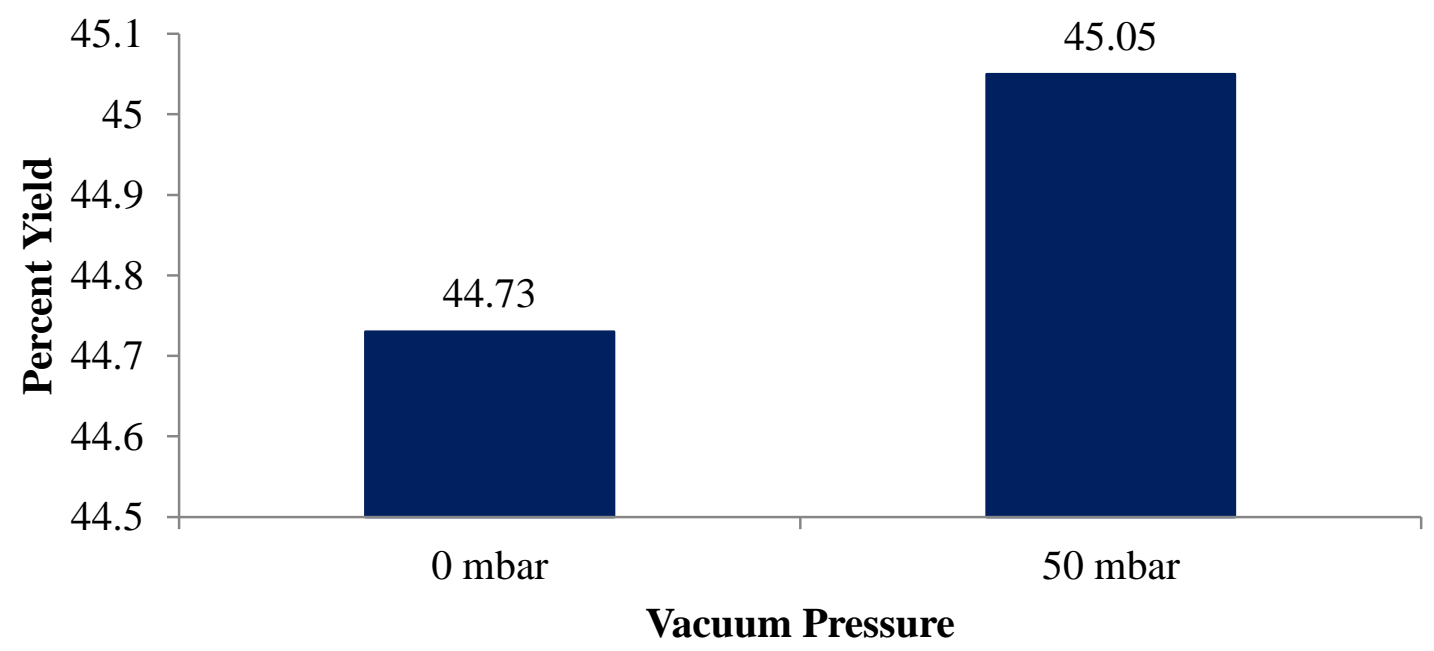

Figure 11: Effect of vacuum pressure on percent yield after conventional dehydration.

$$
\text { SEM=1.01 }
$$




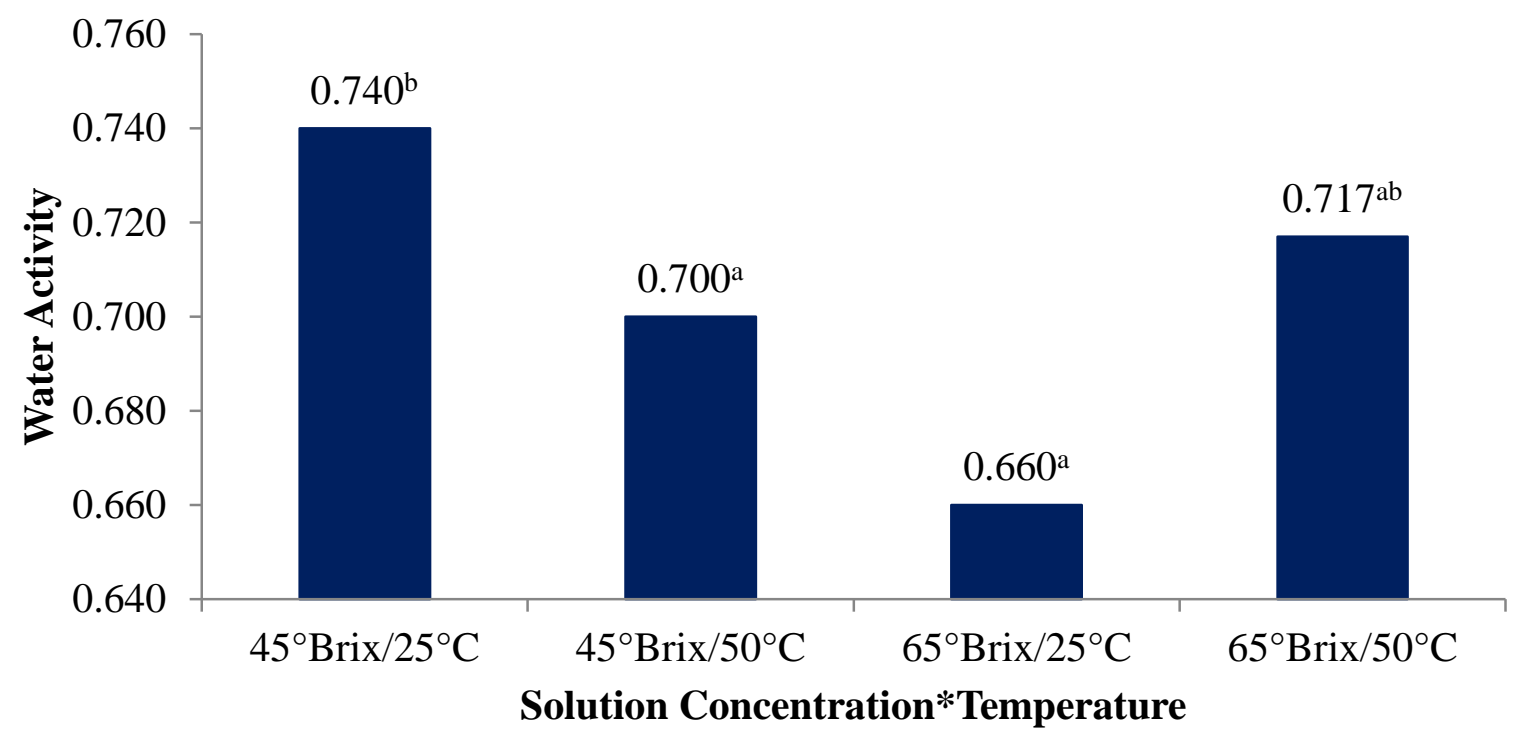

Figure 12: Effect of solution concentration and temperature on final $\mathbf{A}_{\mathbf{w}}$. ${ }^{a b} \mathbf{p}<0.05 ;$ SEM $=0.020$

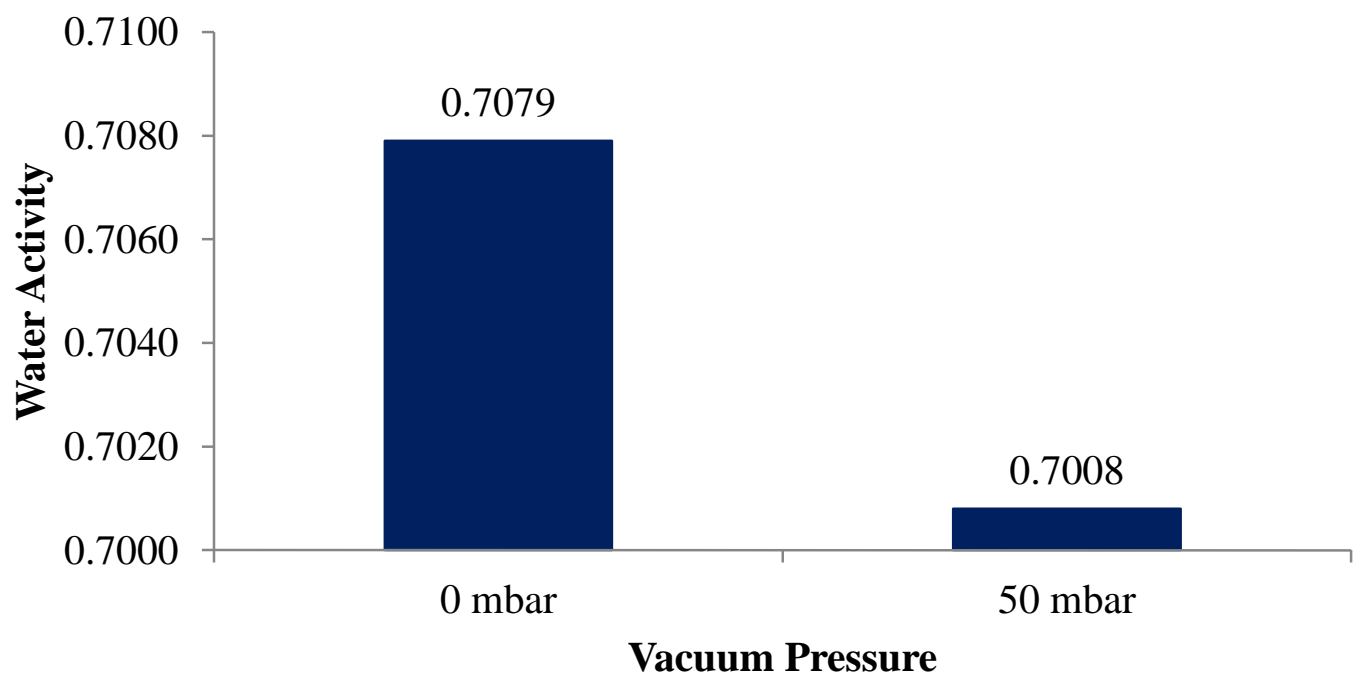

Figure 13: Effect of vacuum pressure on final $A_{w}$. SEM=0.014 


\section{References}

Dalla Rosa, M., Giroux, F. 2001. Osmotic treatments (OT) and problems related to the solution management. Journal of Food Engineering 49: 223-236.

Derossi, A., De Pilli, T., Severini, C. 2012. The application of vacuum impregnation techniques in food industry. In Valdez, B. (Ed.), Scientific, Health and Social Aspects of the Food Industry: InTech. Pp.:25-56.

Escriche, I., García-Pinchi, R., Andrés, A., Fito, P. 2000, Osmotic dehydration of kiwifruit (Actinidia chinensis): fluxes and mass transfer kinetics. Journal of Food Process Engineering 23: 191-205.

Fito, P., Chiralt, A., Martínez-Monzó, J., Barat, J. 2002. Hydrodynamic mechanisms in plant tissues during mass transport operations. In: Welti-Chanes, J., Velez-Ruiz, J. F. (Eds.), Transport phenomena in food processing, Boca Raton, Florida. Pp.: 125-136.

İspir, A., Türk Toğrul, I. 2009. Osmotic dehydration of apricot: Kinetics and the effect of process parameters. Chemical Engineering Research and Design 87: 166-180.

Geisler M. 2012. Blueberries Profile. Agricultural Marketing Resource Center.

Gianotti, A., Sacchetti, G., Guerzoni, M.E., Dalla Rosa, M. 2001. Microbial aspects on shorttime osmotic treatment of kiwifruit. Journal of Food Engineering 49: 265-270.

Giraldo, G., Talens, P., Fito. P., Chiralt, A. 2003. Influence of sucrose solution concentration on kinetics and yield during osmotic dehydration of mango. Journal of Food Engineering 58: $33-43$.

Martínez-Valencia, B.B., Abud-Archilla, M., Ruiz-Cabrera, M.A., Grajales-Lagunes, A., Dendooven, L., Ovando-Chacón, S.L., Gutiérrez-Miceli, F.A. 2011. Pulsed vacuum osmotic dehydration kinetics of melon (Cucumis melo L.) var. cantaloupe. African Journal of Agricultural Research 6: 3588-3596.

Moreno, J., Simpson, R., Baeza, A., Morales, J., Muñoz, C., Sastry, S., Almonacid, S. 2012. Effect of ohmic heating and vacuum impregnation on the osmodehydration kinetics and microstructure of strawberries (cv. Camarosa). Food Science and Technology 45:148154.

Nuñez-Mancilla, Y., Pérez-Won, M., Uribe, E., Vega-Gálvez, A., Di Scala, K. 2012. Osmotic dehydration under high hydrostatic pressure: Effects on antioxidant activity, total phenolic compounds, vitamin $\mathrm{C}$ and colour of strawberry (Fragaria vesca). Food Science and Technology 1-6. 
Shi, J., Maguer, M.L. 2003. Mass transfer in cellular material at solid-liquid contacting interface. LWT-Food Science and Technology 36:3-11.

Shi, X.Q., Fito, P., Chiralt, A. 1995. Influence of vacuum treatment on mass transfer during osmotic dehydration of fruits. Food Research International 28: 445-454. 


\section{Chapter 3: Effect of Vacuum Pressure on Dried Blueberry Yield and Water Activity Introduction}

In the previous experiment, no significant difference in any response was found for vacuum pressure. Most studies on vacuum impregnation and pulsed vacuum osmotic dehydration show that vacuum pressures do profoundly affect final yield and water activity $\left(\mathrm{A}_{\mathrm{w}}\right)($ Giraldo et al., 2003; Martínez-Valencia et al., 2011; Shi et al., 1995). One concern from the last study was that the vacuum pressure was not high enough. To determine if vacuum pressure was truly insignificant, a small experiment was performed using varying levels of vacuum pressure.

\section{Materials and Methods and Statistical Analysis}

Materials and methods performed were nearly identical to the original study. The experiment was designed as a linear regression with 4 levels: no vacuum, 100 mbar, 200 mbar, and 300 mbar vacuum pressures. Most research on vacuum in osmotic dehydration shows that acceptable vacuum pressures are between 100 mbar-600 mbar (Martínez-Valencia et al., 2011; Shi et al., 1995). 5 replicates were performed. Pressures were maintained for 15 minutes at the start of the osmotic dehydration step as in the previous study. Temperature, treatment duration, and solution ${ }^{\circ}$ Brix were kept the same for each pressure: $50^{\circ} \mathrm{C}, 5$ hours, and $65^{\circ}$ Brix. After OD, berries were conventionally dehydrated the same way as the previous study: 390 minutes at $57.2^{\circ} \mathrm{C}$.

Data were analyzed using JMP and SAS software (JMP®, Version Pro 11, SAS Institute Inc., Cary, NC, Copyright $\odot 2013$; SAS®, Version 9.3, SAS Institute Inc., Cary, NC, Copyright (O2002-2010). Significance criterion alpha for all tests was 0.05 . Simple linear and polynomial regression analyses were done regressing $\mathrm{A}_{\mathrm{w}}$ on vacuum pressure, percent yield after OD on vacuum pressure, and percent yield after $\mathrm{CD}$ on vacuum pressure. 


\section{Results}

\section{Percent Yield after $O D$}

Figure 14 shows vacuum pressure's effect on percent yield. Typically, vacuum pressure does help sugar penetrate the fruit. A trend in increasing percent yield was shown, with higher vacuums having higher yields. However, this study showed no significant difference despite varying the pressure dramatically from the original study. Other studies (Giraldo et al., 2003; Martínez-Valencia et al., 2011; Shi et al., 1995) were successful in showing a significant effect of vacuum, though they used much more porous fruits than blueberries.

\section{Percent Yield after $C D$}

Effect of vacuum pressure on percent yield after conventional dehydration can be seen in figure 15. Again, no significant difference was noted between pressures. Based on other research papers, an increase in yield was expected with higher vacuum pressures (Giraldo et al., 2003; Martínez-Valencia et al., 2011; Shi et al., 1995). The results show no pressure and 100 mbar as having the higher yields, and the higher pressures (200 mbar and $300 \mathrm{mbar}$ ) as having lower yields. While, expected outcomes were not reached, the results can be explained by looking at figure 17 , which shows the lower yields having a lower $\mathrm{A}_{\mathrm{w}}$.

\section{Final $A_{w}$}

No significant conclusion could be drawn about vacuum pressure's effect on final $A_{w}$, figure 17. A trend can be seen with decreasing $A_{w}$ with increasing pressure; however the trend was not continued at 300 mbar. By comparing figures 15 and 16, we can speculate that while vacuum pressure does not affect sugar gain, perhaps it does affect water loss to an extent. More studies would be done to confirm this effect though. 


\section{Conclusions}

Similar to the original study, vacuum pressures up to 300 mbar were not shown to significantly affect final $A_{w}$ or yield in blueberries. While trends were noted, no significance could be found. Exploring this area further could help enhance knowledge on blueberry structure and how it may affect mass transfer. 


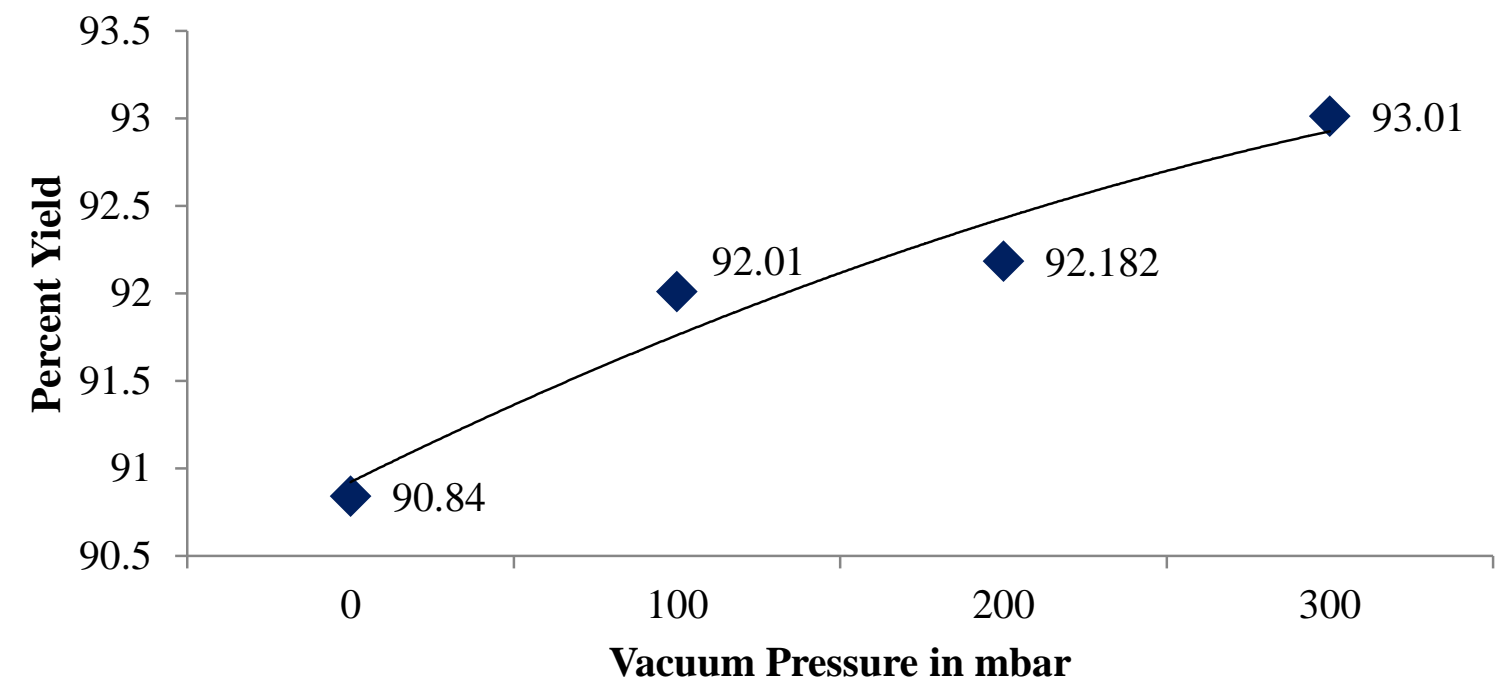

Figure 14: Effect of vacuum pressure on percent yield after osmotic dehydration.

RMSE=2.328.

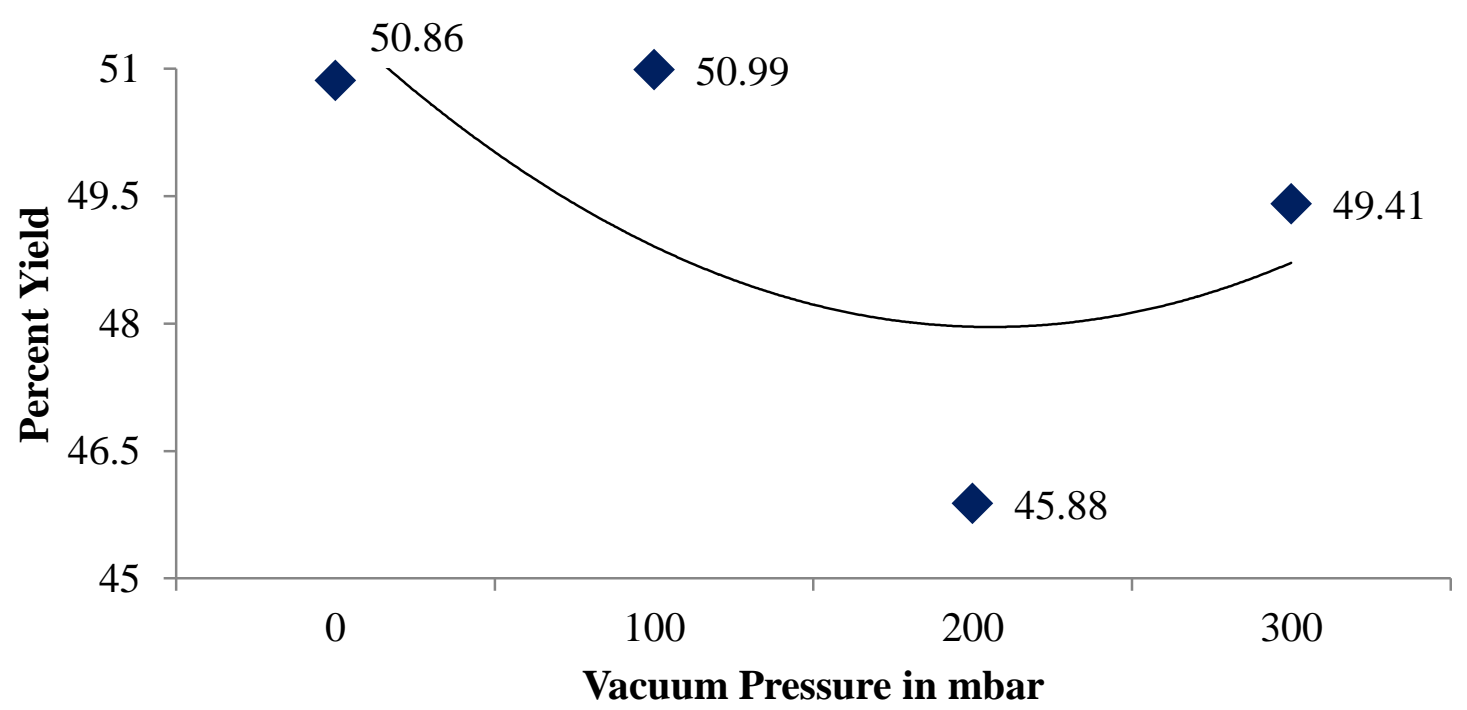

Figure 15: Effect of vacuum pressure on percent yield after conventional dehydration.

RMSE=7.011. 


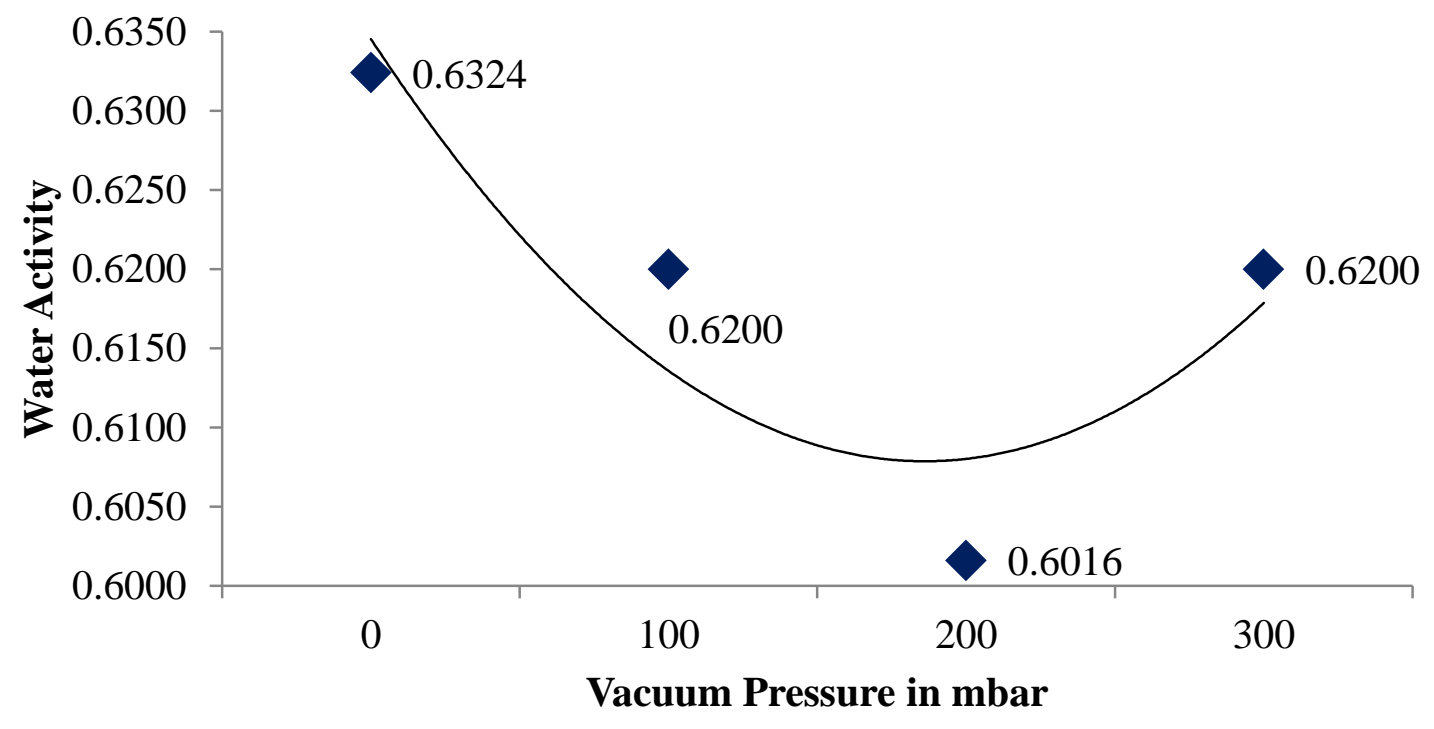

Figure 16: Effect of vacuum pressure on final water activity. RMSE $=\mathbf{0 . 0 5 4}$ 


\section{References}

Giraldo, G., Talens, P., Fito. P., Chiralt, A. 2003. Influence of sucrose solution concentration on kinetics and yield during osmotic dehydration of mango. Journal of Food Engineering 58: 33-43.

Martínez-Valencia, B.B., Abud-Archilla, M., Ruiz-Cabrera, M.A., Grajales-Lagunes, A., Dendooven, L., Ovando-Chacón, S.L., Gutiérrez-Miceli, F.A. 2011. Pulsed vacuum osmotic dehydration kinetics of melon (Cucumis melo L.) var. cantaloupe. African Journal of Agricultural Research 6: 3588-3596.

Shi, X.Q., Fito, P., Chiralt, A. 1995. Influence of vacuum treatment on mass transfer during osmotic dehydration of fruits. Food Research International 28: 445-454. 